\title{
SITE-INVESTIGATION AND GEOTECHNICAL DESIGN OF D-RUNWAY CONSTRUCTION IN TOKYO HANEDA AIRPORT
}

\author{
Yoichi WAtABE ${ }^{\text {i) }}$ and TAKatoshi Noguchi ${ }^{\text {ii) }}$
}

\begin{abstract}
Tokyo International Airport (Haneda Airport) is a domestic hub-airport in Japan; however, the increasing number of passengers has brought it close to its capacity. In addition, there has been strong demand for the development of an international-flight network. Consequently, a new runway, called the "D-runway," was planned and constructed from March 2007 to October 2010. Because some of the D-runway runs through a river mouth, a hybrid structure consisting of piled pier and reclamation fill was adopted. To overcome the geotechnical difficulties in constructing this hybrid structure on the soft clay deposit, various technologies in design and construction were adopted. This paper provides an outline of the project, the ground investigation, and the design of the D-runway structure from a geotechnical engineering view point. From the results of the site investigation, the stratigraphic model at the site was clarified. For the clay layers, a representative depth-profile for each soil parameter was determined. Some local soil properties which tended to be overlooked when only employing an engineering point of view can be appropriately captured by linking the geological and geotechnical information. In the construction of the D-runway, not only the ground improvement technologies (SD, SCP, and CDM) but also the new developed construction materials (the pneumatic mixing of cement treated soil and air-foam treated lightweight soil) were utilized. In the-D-runway project, various technologies used in previous airport constructions were brought together and applied to the ground investigation, design, construction work, and even maintenance. The construction of the D-runway was completed safely, rapidly, and economically, and it came into use on 21 October 2010, on schedule.
\end{abstract}

Key words: design, ground improvement, lightweight soil, reclamation, site investigation, soil parameter (IGC: $\mathrm{B} 6 / \mathrm{H} 6)$

\section{INTRODUCTON}

Tokyo International Airport (Haneda Airport) was developed by reclaiming land on the sea. The offshore expansion project, which started in 1984 , was an epochmaking project, involving the construction of an airport island from dredged clay disposal facilities in the ultra soft state (Katayama, 1991). After the offshore expansion project, three runways (A, B and C-runways) were in operation. Recently, the annual number of passengers has been about $65,000,000$, which is equivalent to approximately $60 \%$ of the total number of domestic passengers in Japan. The airport has taken a role as domestic hub-airport with about 50 airline routes. The number of international flights has been limited; however, shortrange international airline routes are in-service between Haneda Airport and Gimpo International Airport (Korea), Beijing Capital International Airport (China), Hong Kong International Airport (China), and Shanghai Hongqiao International Airport (China).

Haneda Airport has mainly taken on the role of domestic hub, because if the clear distinction made be- tween the role of this airport, the domestichub, and Narita International Airport (formerly, New Tokyo International Airport), the international hub. Although the

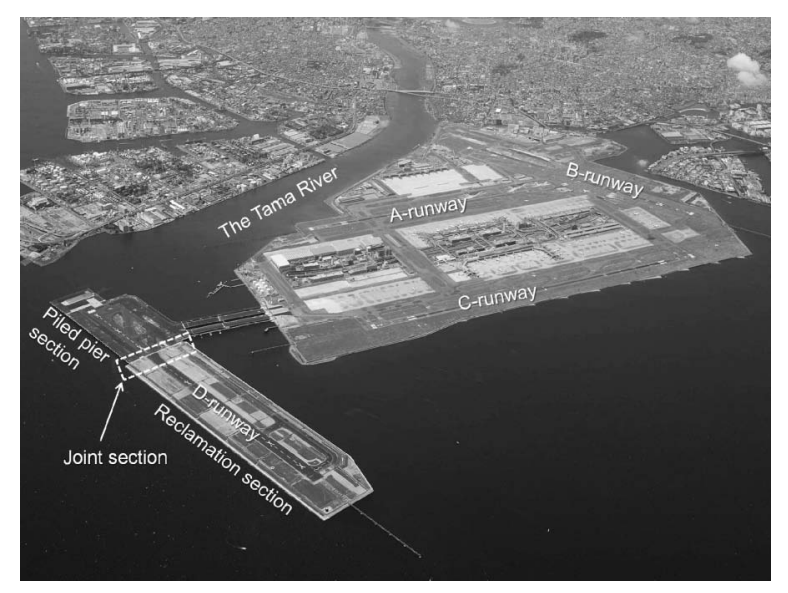

Photo 1. The D-runway construction. This photograph was taken on 18 July 2010

i) Leader of Soil Mechanics and Geo-environment Research Group, Port and Airport Research Institute, Japan (watabe@ipc.pari.go.jp).

ii) Kanto Regional Development Bureau, Ministry of Land, Infrastructure, Transport, and Tourism, Japan

The manuscript for this paper was received for review on December 1, 2010; approved on June 8, 2011.

Written discussions on this paper should be submitted before July 1, 2012 to the Japanese Geotechnical Society, 4-38-2, Sengoku, Bunkyo-ku, Tokyo 112-0011, Japan. Upon request the closing date may be extended one month. 
number of passengers is close to capacity, passenger demand is still increasing. In addition, because of accessibility from large cities such as Tokyo and Yokohama, there is a strong social demand to develop authentic international airline routes.

To meet these social demands, the fourth runway, named "D-runway", was newly constructed to increase capacity (Photo 1). This project plans to allow for an increase in capacity from approximately 300,000 annual flights to approximately 450,000 annual flights. The Drunway started operation in October 2010 on schedule.

The D-runway project is explained in this paper, with a discussion on the ground investigation, and the design of the manmade island, from a geotechnical engineering perspective.

\section{OUTLINE OF THE D-RUNWAY PROJECT}

In planning the D-runway project, "Construction method assessment committee for the further offshore expansion project of Haneda Airport" concluded that three construction methods, i.e., "pier structure," "hybrid structure of pier and reclamation fill," and "massive floating structure,', were feasible. In signing the contract, a blanket order of design and construction was adopted, including 30-year maintenance.

Actually, a joint-venture group of 15 companies including general contractors, marine contractors, steel manufacturing companies, engineering companies, and electric works companies decided to make a proposal based on the hybrid structure of pier and reclamation fill, and the proposal was finally accepted by the client. The contract was signed in March 2005, then an environmental assessment was carried out, an application for approval of reclamation was made, fisheries were compensated, and construction began on 30 March, 2007. When the construction was completed, the D-runway went into operation on 21 October, 2010.

In the D-runway project, the bidding group was entrusted with the responsibility of selecting the construction method and the preliminary design. The in-service period in design was set at 100 years, which is considerably longer than ordinary civil engineering structures. After being signed up, the contractor drew up an execution design, then the design was examined by the client before construction commenced. The geotechnical risk and material risk in association with natural heterogeneity and a large-volume order, respectively, were, in principle, the responsibility of the contractor.

Both the site plan of the D-runway and previous airport facilities are shown in Fig. 1. The D-runway is located $600 \mathrm{~m}$ offshore from the previous airport island. In the area inside the river mouth of the Tama River, a pier structure with an impediment rate of river flow less than $8 \%$ was adopted to ensure a sufficient flow rate during times of floods. The length of the D-runway is $2500 \mathrm{~m}$. The elevation at the offshore end of the D-runway was required to be higher than A.P. (Arakawa Peil) $+17.1 \mathrm{~m}$, which is much higher than ordinary manmade islands,

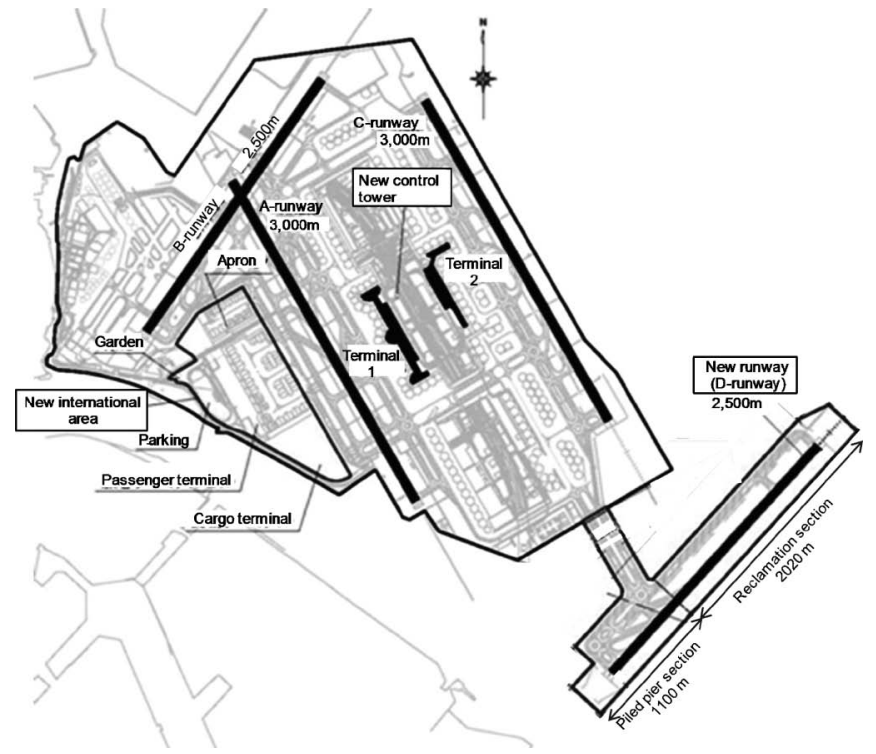

Fig. 1. Site plan of the D-runway and previous airport facilities

because airplanes have to pass over large ships navigating nearby. Although it is called "a manmade island," it may well be more accurately referred to as a "high embankment" because of the water depth of about $20 \mathrm{~m}$.

Head clearance at the construction site was extremely limited, because the working area was under the flight route from/to the C-runway. Consequently, construction work using equipment higher than head clearance had to be done during the nighttime when the C-runway was closed. During the construction period, the C-runway was closed from $20: 45$ to $7: 45$. Because the working area was close to the Tokyo Navigation Channel No. 1, which is heavily navigated by large cargo ships, the navigation of working vessels needed to be safely controlled. Because the work period was so strictly limited for this large construction project, construction work was conducted 24 hours a day and 365 days a year.

\section{GEOTECHNICAL INVESTIGATION}

\section{Outline of the Investigation}

At the sea area where the D-runway construction was planned, boring and sampling investigation up to A.P. $-100 \mathrm{~m}$ (partly A.P. $-200 \mathrm{~m}$ ) were carried out at the points shown as solid circles in Fig. 2, i.e., A1-A14 at the D-runway main structure and B1-B3 at the access taxiway structure. Collected clay samples were examined in the laboratory by physical properties tests such as the liquid limit test, plastic limit test, particle density test, and grain-size distribution test. Shearing tests, such as unconfined compression test and triaxial UU compression test with a confining pressure equivalent to the overburden effective stress $\sigma_{\mathrm{v} 0}^{\prime}$, and incremental loading consolidation test, were also carried out. The scene of the site investigation of the seabed is shown in Photo 2.

The test results were presented as "The Reference Geotechnical Data Sets for D-runway Project (Kanto 
Regional Development Bureau, Ministry of Land, Infrastructure, Transport and Tourism, 2004)', which was thought to be a sort of geotechnical baseline report (Essex, 2007) for bidding. After the bidding and signing up the contract, an additional geotechnical investigation was carried out at the points shown as hollow marks in Fig. 2, after taking the fact that the direction of the Drunway was rotated clockwise by $7.5^{\circ}$ around boring point A-2 into consideration.

\section{Results of the Investigation}

The geological cross-section in the D-runway direction in the original plan is shown in Fig. 3 with boring logs and depth profiles of $N$-value. In the D-runway project, the names of the soil layers reflect the geological history;

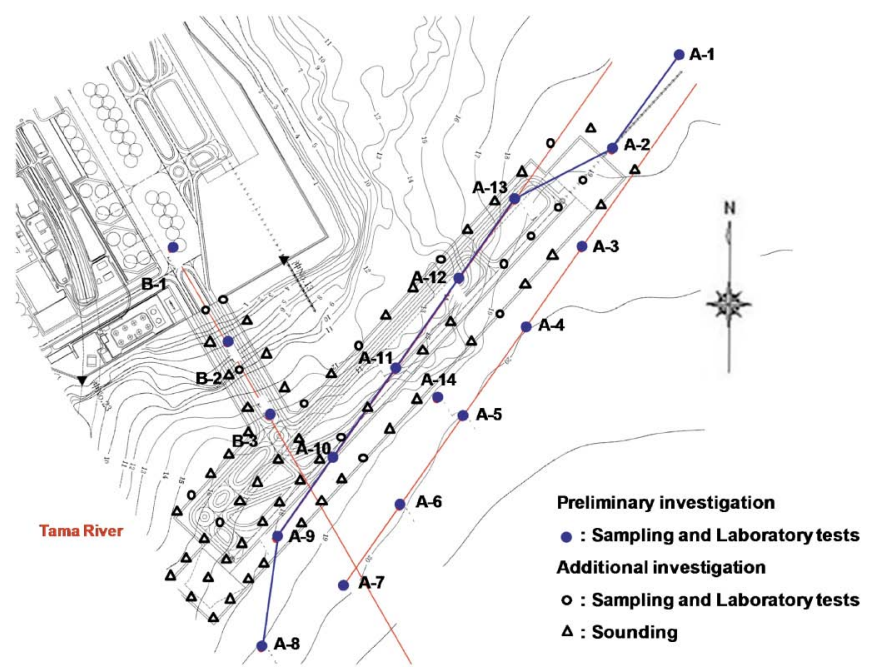

Fig. 2. Site map of the ground investigation points i.e., Y (Yurakucho layer), Na (Nanago layer), To (Tokyo layer), and Ed (Edogawa layer). Subscripts c, s and g express clay, sand and gravel layers, respectively. The interface between Yuc and Ylc is almost horizontal; however, the lower boundary of Ylc is slightly deeper around the south-west end of the D-runway (side of the Tamagawa River). In most of the Na layer, Nac and Nas was deposited alternately. In Haneda Airport, soil layers above and below A.P. - $35 \mathrm{~m}$ were called A (alluvial) and D (diluvial), respectively, classified according to their engineering properties. This classification, however, was incorrect from geological sense, because the layers up to $\mathrm{Na}$ should be classified as alluvial from a geological viewpoint.

The Na layer at A-13 deposited deeper and thicker than that at others, indicating that the Nac at A-13 deposited in an eroded valley in Tokyo layer. In A-2 and A-1, buried terrace gravel deposits (btg) were found between the

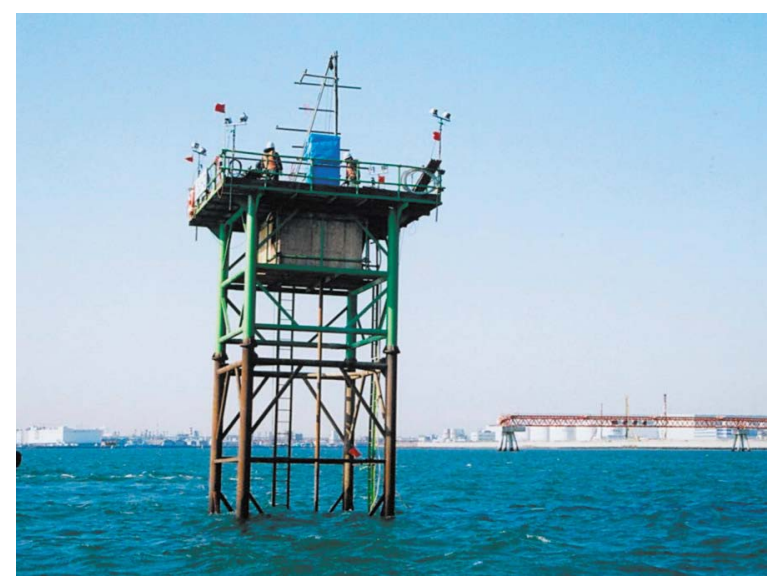

Photo 2. Carrying out the site investigation of the seabed

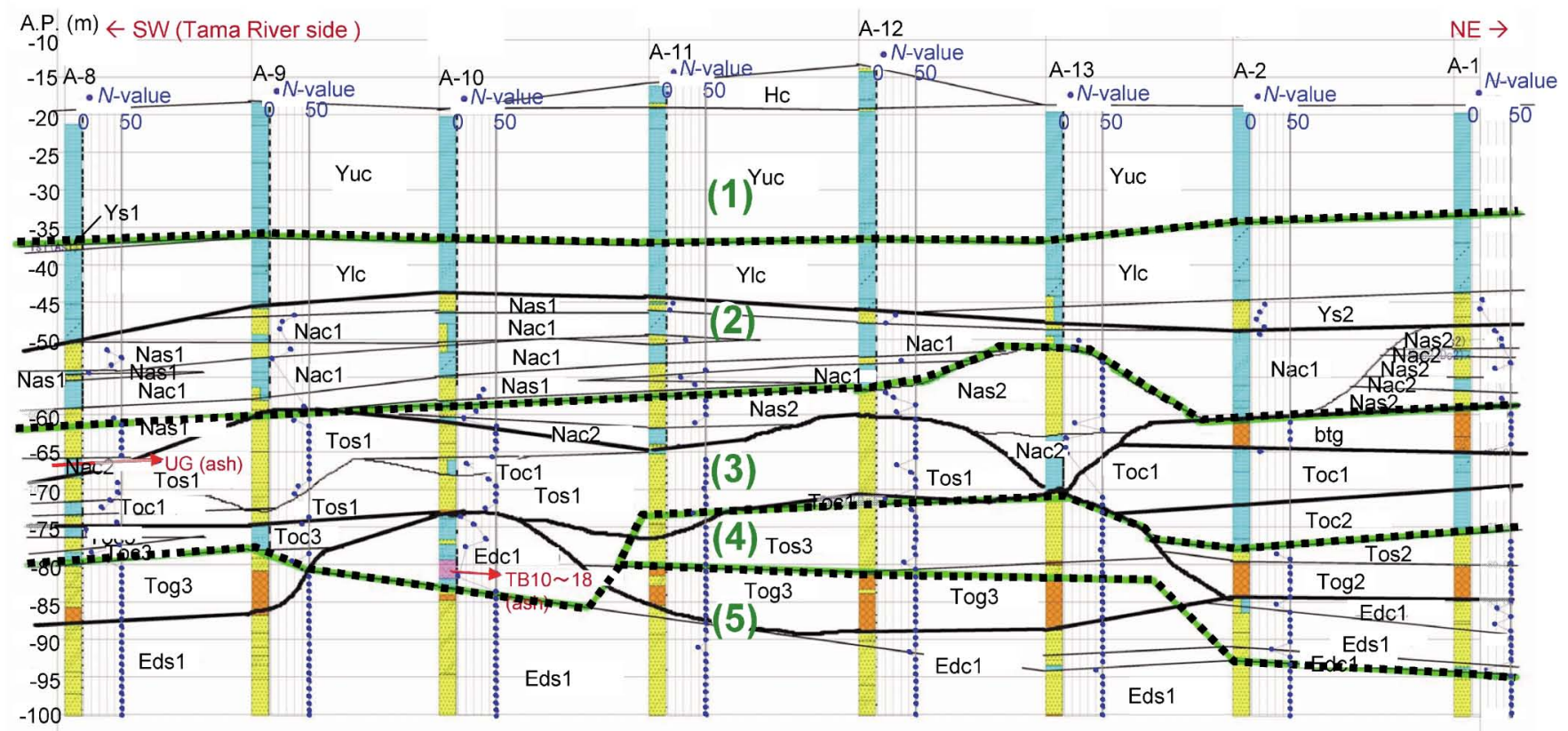

Fig. 3. The geological cross-section with depth profiles of $N$-value in the D-runway direction in the original plan 


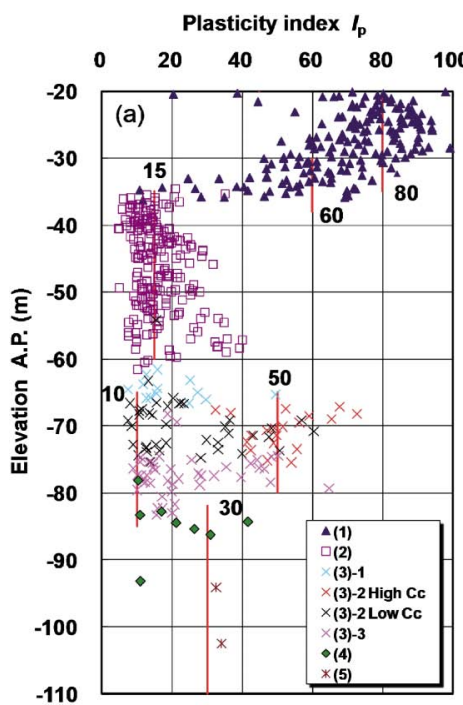

Natural water content $w_{n}(\%)$

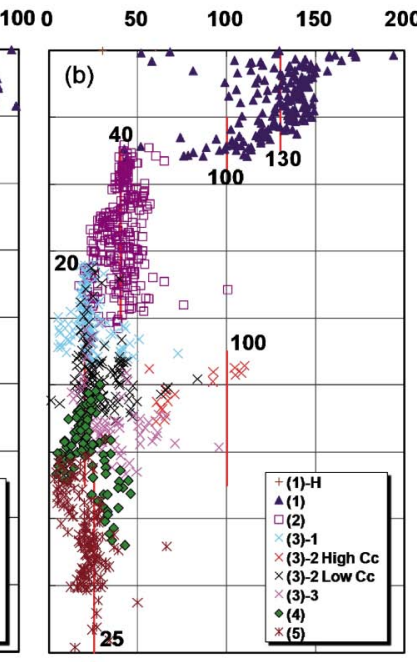

Fig. 4. Depth profiles of the physical properties: (a) plasticity index; (b) natural water content

$\mathrm{Na}$ and To layers at around A.P. $-60 \mathrm{~m}$. The base gravel layer (Tog) at the bottom of To layer was found out at most points. The Tokyo layer (To) consists mainly of sandy soils; however, a clay deposit with a thickness of 10-15 m was deposited at both A-2 and A-1. The Ed layer consists of stiff sandy soil. Below the Tog layer is a very stiff sand layer, which is equivalent to bed rock, with an $N$-value larger than 50. The sand layer of To also has an $N$-value larger than 50 where it has a sufficient thickness. The sand layers of $\mathrm{To}$ and $\mathrm{Na}$ can support piled foundations; however, their thicknesses must be examined carefully, particularly in the case of large structures.

The depth profiles of test results obtained from A1-A14 are shown in Figs. 4 and 5. Because the geological cross-section at the construction site was relatively homogeneous in the horizontal direction, these integrated graphs can express the representative depth profiles for the D-runway construction site. The representative depth profiles of each soil parameter are indicated by the straight lines. From these test results for clay samples as well as standard penetration test results ( $N$-value) for sandy layers, i.e., from geotechnical engineering view point, the ground cross-section was classified into 5 layers (1)-(5) from the surface. This classification is not consistent with the geological classification; however, it is very important in designing.

In Japan, airport foundations constructed on the sea, e.g., seawalls for reclamation, are designed following the design code for port facilities. The design code (Japan Port and Harbour Association, 2007; Overseas Coastal Area Development Institute of Japan, 2009) was significantly revised, and it adopted a new determination method for soil parameters (Watabe et al., 2009). However, because the design of D-runway was conducted before this revision, it followed the previous version of the design code (Japan Port and Harbour Association, 1999; Overseas Coastal Area Development Institute of Japan, 2002). Therefore, the average value of the test
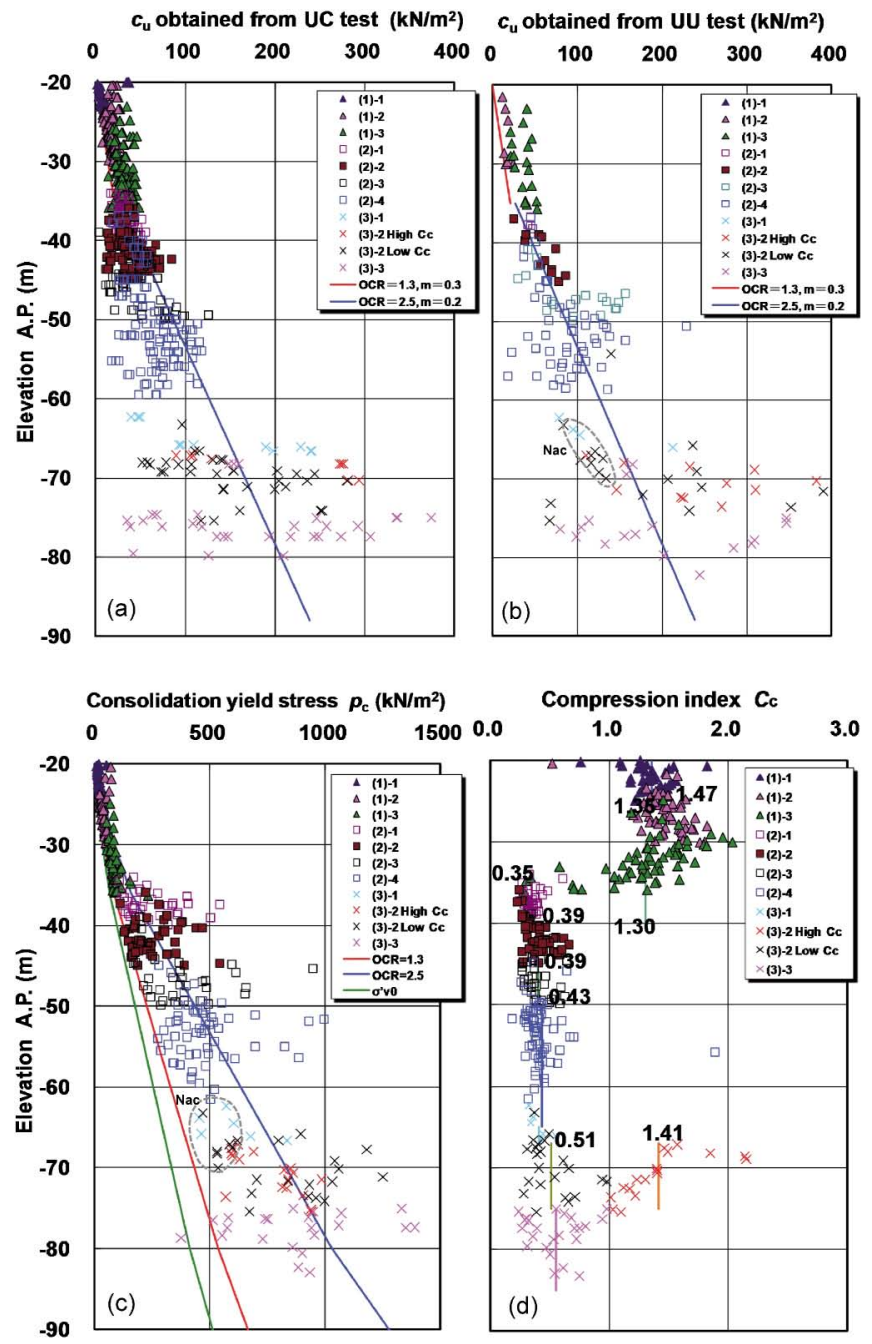

Fig. 5. Depth profiles of the mechanical properties: (a) undrained shear strength $c_{\mathrm{u}}$ obtained from unconfined compression test (UC test); (b) undrained shear strength $c_{\mathrm{u}}$ obtained from triaxial UU test with confining pressure of $\sigma_{\mathrm{v} 0}^{\prime}$; (c) consolidation yield stress $p_{\mathrm{c}}$; (d) compression index $C_{\mathrm{c}}$. The areas surrounded by dotted line in (b) and (c) indicate the regions of the data for Nac below A.P. $-60 \mathrm{~m}$

results, coupled with engineering judgment, which leads to improved safety in design, should be used as the design value. In addition, the stress history and commonsensical range of the soil parameters were considered. The representative values of the soil parameters, such as undrained shear strength and consolidation yield stress, are indicated as straight lines in the figures.

\section{(a) Layer (1): Seafloor Surface to A.P. $-35 \mathrm{~m}$}

This layer is very homogeneous soft clay deposit in the normal consolidation state. The natural water content $w_{\mathrm{n}}$ is in the range of $100-150 \%$, plasticity index $I_{\mathrm{p}}$ is approximately 80 , and fine-particle content ( $<75 \mu \mathrm{m})$ is approximately $100 \%$. Undrained shear strength can be determined based on the unconfined compression test (UC test) results.

Because the soil is considered to be lightly overconsolidated (Fig. 5(c)), strength increase ratio $m=c_{\mathrm{u}} / \sigma_{\mathrm{vc}}^{\prime}$ is coincident with $c_{\mathrm{u}} / p_{\mathrm{c}}$, where $\sigma_{\mathrm{vc}}^{\prime}$ is a consolidation stress 
in normal consolidation range, $p_{\mathrm{c}}$ is the consolidation yield stress. This clay layer is in quasi-overconsolidation due to the aging effect rather than mechanical overconsolidation. Therefore, it is reasonable to assume that $m=$ $c_{\mathrm{u}} / \sigma_{\mathrm{vc}}^{\prime}=c_{\mathrm{u}} / p_{\mathrm{c}}$ (Hanzawa, 1983; Watabe et al., 2009). The strength increase ratio $m=c_{\mathrm{u}} / p_{\mathrm{c}}$ is calculated to be 0.41 , which is significantly larger than the range of $m=$ 0.25-0.30 obtained for many other clays (Mesri, 1975; Watabe et al., 2003). The overconsolidation ratio $\mathrm{OCR}=$ $p_{\mathrm{c}} / \sigma_{\mathrm{v} 0}^{\prime}$ is calculated to be 1.50 , where $\sigma_{\mathrm{v} 0}^{\prime}$ is the overburden effective stress. Relatively larger undrained shear strengths near the surface were locally obtained at the area with cover sand (Hc in Fig. 3) around the previous airport island.

At the reclamation section, strength increase with progress of consolidation after filling can be expected in staged construction. It was feared that the direct use of $m$ $=0.41$ may lead to an overestimation of the strength increase. In addition, the overconsolidation ratio OCR for the clay in quasi-overconsolidation should not be so large. In this project, consequently, the strength increase ratio $m$ and overconsolidation ratio OCR were set at 0.3 and 1.3 , respectively, which are slightly smaller values than those mentioned above (Kanto Regional Development Bureau, Ministry of Land, Infrastructure, Transport and Tourism, 2004).

\section{(b) Layer (2): Around A.P. $-35 m$ to around A.P. $-60 m$}

This layer is a low plastic clay deposit with a relatively high sand fraction; however, this is classified into a socalled clay considered undrained in design (Nakase, 1967), according to the design code for port facilities in Japan (Japan Port and Harbour Association, 1999, 2007; Overseas Coastal Area Development Institute of Japan, 2002, 2009). In the lower half layer, some thin sand layers are alternately deposited. Because a plasticity index $I_{\mathrm{p}}$ as low as 15 tends to be a cause of sample disturbance, the undrained shear strength obtained by the unconfined compression test is significantly smaller than that obtained by the triaxial UU compression test. Consequently, the undrained shear strength $c_{\mathrm{u}}$ in this layer was determined by the triaxial UU compression test. Note here that the value of $c_{\mathrm{u}}$ from the UU test was confirmed by the recompression triaxial $\mathrm{CU}$ test, in which a soil specimen was consolidated under the stresses equivalent to the in situ condition $\left(\sigma_{1}^{\prime}=\sigma_{\mathrm{v} 0}^{\prime}\right.$ and $\left.\sigma_{3}^{\prime}=K_{0} \sigma_{\mathrm{v} 0}^{\prime}\right)$ and then $c_{\mathrm{u}}$ was determined as the average of compressive and extensive shear strengths (Berre and Bjerrum, 1973; Watabe et al., 2002).

Because mechanical properties are in the same tendency in both Layer (2) and Layer (3), the depth profiles of the undrained shear strength $c_{\mathrm{u}}$ and consolidation yield stress $p_{\mathrm{c}}$ were determined by integrating these two layers. The overconsolidation ratio $\mathrm{OCR}=\sigma_{\mathrm{v} 0}^{\prime} / p_{\mathrm{c}}$ of this layer is calculated to be 2.46 . This value may be a little too large to calculate the strength increase ratio $m$ as $c_{\mathrm{u}} / p_{\mathrm{c}}$, resulting in a smaller $m$ value because of swelling. Despite this, $m$ is calculated with this definition to be 0.18 , which is sig- nificantly smaller than a range of $0.25-0.30$ in geotechnical common sense. In the design, a large circle arc slip possibly passes in this layer. Because this layer is too deep to install drains for ground improvement, soil parameters relating to mechanical properties had to be set very carefully. Consequently, $m$ and OCR were set to be 0.2 and 2.5, respectively (Kanto Regional Development Bureau, Ministry of Land, Infrastructure, Transport and Tourism, 2004).

\section{(c) Layer (3): Around A.P. $-60 m$ to A.P. $-75 m$}

This layer consists of alternate gravel, sand, and clay layers. Some parts, with an $N$-value larger than 50, can function as a bearing layer for a small structure. Clay layers below a sand layer with $N$-value larger than 50 are classified into this layer, e.g., Toc and lower part of Nac. A part of Toc showed a high water content, high plasticity index, and high compression index (see Figs. 3, 4, and 5(d)). Undrained shear strength $c_{\mathrm{u}}$ and consolidation yield stress $p_{\mathrm{c}}$ were able to be expressed by the extrapolation of those depth profiles in layer (2). It is notable that the data for Nac below A.P. $-60 \mathrm{~m}$ are plotted in the region surrounded by the dotted line. The undrained shear strength $c_{\mathrm{u}}$ and consolidation yield stress $p_{\mathrm{c}}$ for younger deposits $(\mathrm{Nac})$ are significantly smaller than those for older deposits (Toc), even though both of these two deposits were found at the same depth. This indicates that some local soil properties, which tend to be overlooked from only an engineering point of view, can be understood by linking the geological and geotechnical information.

Depth profiles of set values of (a) undrained shear strength $c_{\mathrm{u}}$ and (b) consolidation yield stress $p_{\mathrm{c}}$ in "The Reference Geotechnical Data Sets for D-runway Project (Kanto Regional Development Bureau, Ministry of Land, Infrastructure, Transport and Tourism, 2004)'" are shown in Fig. 6, where the set values are compared to the regression lines, characteristic values of soil parameters determined by the new design code for port facilities (Japan Port and Harbour Association, 2007; Overseas Coastal Area Development Institute of Japan, 2009; Watabe et al., 2009), and 95\% confidence level (EN 1997-1, 2004; JGS 4001, 2004). In these figures, the number of plotted data is smaller than in Fig. 5 because the data influenced by Layer Hc (cover sand) are omitted to homogenize the stress history. Because the number of data is sufficient for statistic treatment, the regression lines almost agree with the characteristic values of $95 \%$ confidence level (the difference between them is only $5 \%$ ). As mentioned above, the set values are smaller than the regression lines because they are set by engineering judgment to be on the safe side in terms of design. These set values were modified later corresponding to the observed data in the real construction work.

In the new design code for port facilities, the characteristic value is determined corresponding to the data variation, even though the number of data entries is significantly large. Meanwhile, in EN 1997-1 and JGS 4001, the characteristic value is coincident with the regression 


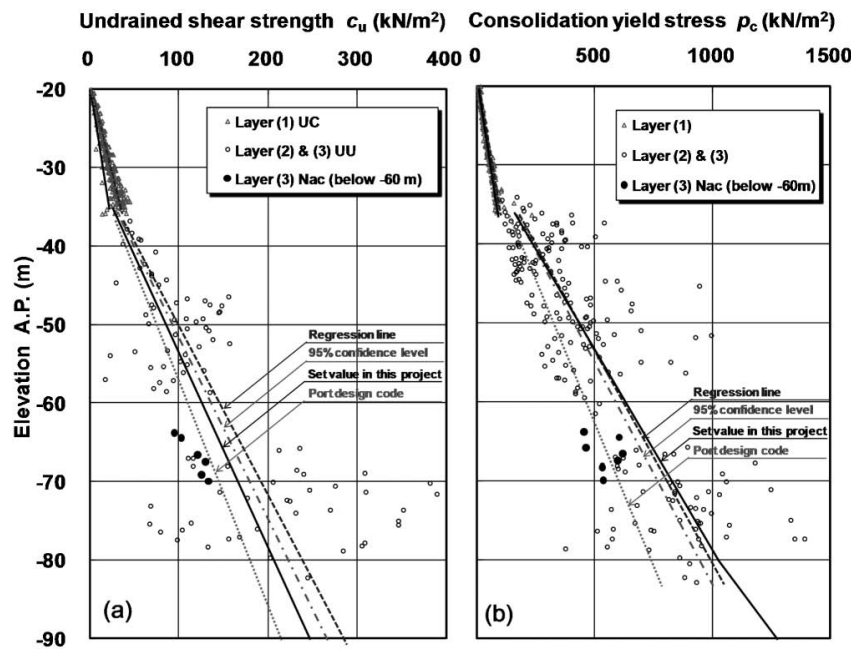

Fig. 6. Depth profiles of the set values of (a) undrained shear strength $c_{\mathrm{u}}$ and (b) consolidation yield stress $p_{\mathrm{c}}$ in this project, comparing to the regression lines, characteristic values of soil parameters determined by the new design code for port facilities, and $95 \%$ confidence level

line (mean depth profile) because the number of data entries is sufficient.

In these investigation results, the characteristic value determined by the new design code for port facilities is significantly smaller than the regression line, because the data shows significant variation, particularly below A.P. $-35 \mathrm{~m}$. As mentioned above, in the case of local data variation such as $\mathrm{Nac}$ with smaller shear strength below A.P. $-60 \mathrm{~m}$, it is very important to consider the data variation even though the number of data entries is significantly large. In fact, the characteristic value determined by the new design code for port facilities corresponds well to the local data variation at Nac below A.P. $-60 \mathrm{~m}$.

\section{(d) Layer (4): Around A.P. $-75 m$ to around A.P. $-90 m$}

This layer was not found in the south-west regions. Although some thin clay layers were deposited alternately, continuous layers with $N$-values larger than 50 can function as bearing layers for middle- to large-size structures.

\section{(e) Layer (5): Deeper than around A.P. $-85 m$}

Because the $N$-value in this layer is continuously larger than 50, this can be a bearing layer for a large-size structure, such as the piled pier of D-runway. Its shear wave velocity is higher than $400 \mathrm{~m} / \mathrm{s}$.

Even though the direction of the D-runway was rotated clockwise by $7.5^{\circ}$ after the ground investigation, these results were almost consistent with the additional ground investigation conducted at the real construction site.

\section{STRUCTURE OF THE D-RUNWAY}

\section{Reclamation Section}

(a) Seawall Type

The reclamation section was constructed on a soft clay seabed as a high embankment with a thickness of approximately $41 \mathrm{~m}$ from the seabed to the top. Because of the settlement, the thickness is larger than the total water depth and the elevation of the runway. Incremental consolidation pressure applied to the seabed surface by this reclamation reached approximately $550 \mathrm{kN} / \mathrm{m}^{2}$. This consolidation pressure, equivalent to that at the second phase island of the Kansai International Airport, is the largest in the history of Tokyo Bay.

A mild slope rubble seawall was adopted for the general seawall section $(4144.1 \mathrm{~m})$, and a gravity type caisson seawall was adopted for the approach light seawall (100.2 $\mathrm{m})$ and tentative quay wall $(221.0 \mathrm{~m})$. Considering the time and cost constraints, it was not considered reasonable to strengthen the very thick soft clay deposit before reclamation. Consequently, the mild slope rubble seawall, which allows a certain level of settlement and lateral movement, was utilized to the general seawall section. The mild slope rubble seawall is the technology adopted in the construction of the Kansai International Airport (Watabe et al., 2002; Furudoi, 2010). This seawall type is very nature-friendly, and becomes a fishing reef and sea grass field.

\section{(b) Mild Slope Rubble Seawall}

The mild slope rubble seawall was utilized to the general seawall section because of its flexibility considering both settlement and lateral movement. A typical crosssection is shown in Fig. 7. The sand compaction pile method with a replacement ratio of $30 \%$ (low replacement ratio SCP) was utilized to improve the stability of the composite ground and to accelerate the consolidation by drainage. A working scene of the SCP installation is shown in Photo 3. The SCP pile arrangement was $3.0 \mathrm{~m}$ $\times 3.5 \mathrm{~m}$.

The shallow soft clay deposit at A.P. $-20 \mathrm{~m}$ to A.P. $-35 \mathrm{~m}$ (Layer (1)-C. Note "CC" refered to as the clayey layer, hereafter) has a relatively small coefficient of consolidation $c_{\mathrm{v}}$ of approximately $100 \mathrm{~cm}^{2} /$ day, indicating that consolidation would require a long period. Consequently, ground improvement technology was required for this layer. Below this layer, however, low plastic sandy silt at A.P. $-35 \mathrm{~m}$ to A.P. $-60 \mathrm{~m}$ (Layer (2)-C) has relatively large $c_{\mathrm{v}}$ of approximately $1000 \mathrm{~cm}^{2} /$ day, indicating that consolidation was expected to be completed within a short period. Residual settlement in Layer (2)-C was also expected to be small. Consequently, ground improvement technology was not required for this layer. Accordingly, Layer (1)-C was completely improved by SCP, however, Layer (2)-C was partly improved by SCP. The SCP piles were installed up to A.P. $-42 \mathrm{~m}$ (20 to 25 $\mathrm{m}$ below the seafloor surface). This improvement depth was determined with the stability in mind.

Around the slope end of the seawall, the ground sur- 


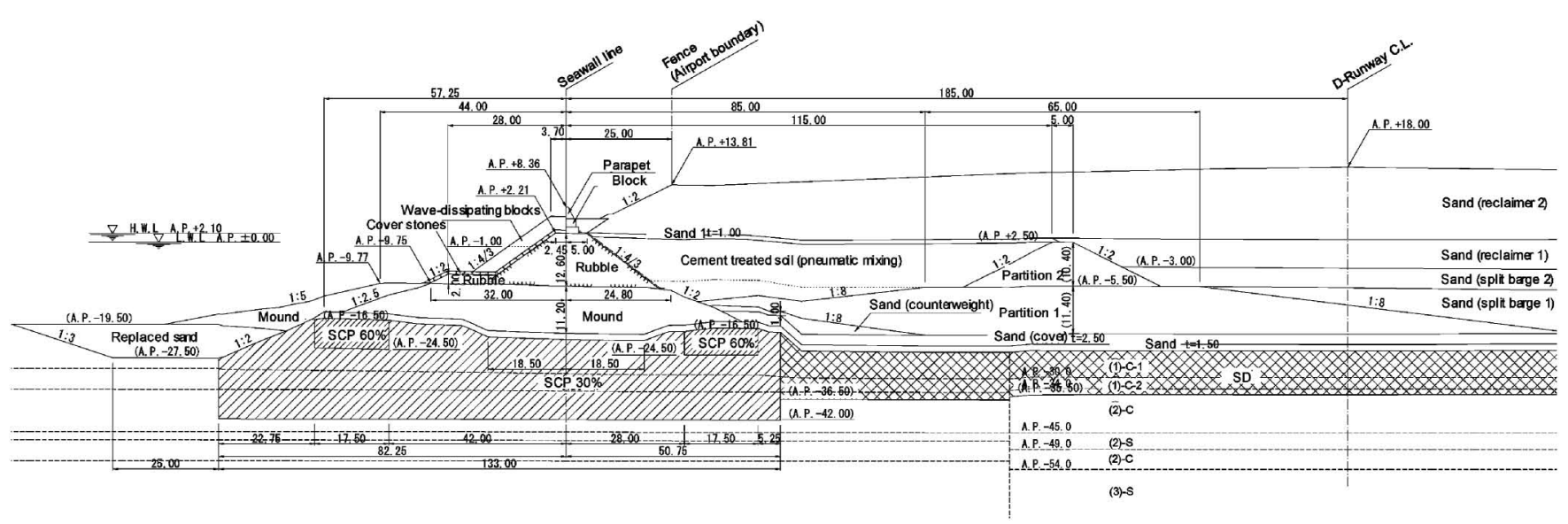

Fig. 7. A typical cross-section of the mild slope rubble seawall (general seawall section)

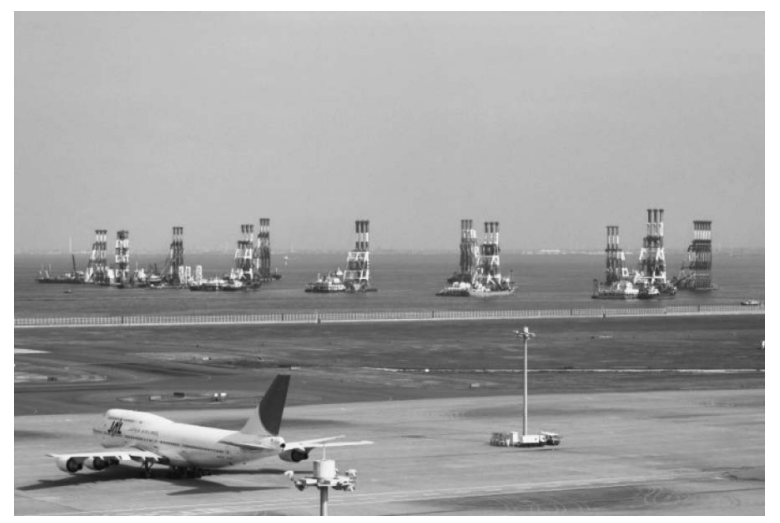

Photo 3. The SCP installation

face was improved by $\mathrm{SCP}$ with a replacement ratio of $60 \%$ to ensure stability. Because the smear effect was a matter of concern in the clay between SCPs, the determining the size of the section to be improved involved considering the stability of the seawall without the drain effect before the main body of the rubble seawall was completed. The total length of SCP, including the SCP in the joint section, was approximately $1,360,000 \mathrm{~m}$.

In addition, the soft clay seabed in front of the seawall was excavated by dredging and was replaced by sand as a counterweight. The dredged clay was cement treated and backfilled as a lightweight soil. These two technologies of counterweight and lightweight soil contribute to improving the stability of the seawall. Dredged clay from the moving work of the Tokyo Navigation Channel No. 1 was also utilized for the lightweight soil.

Because of the short construction period, construction had to go ahead when the degree of consolidation had only reached $50 \%$. Consequently, observational construction was strongly required. In the observation, surface settlement, stratified settlement, and the depth profile of the horizontal displacement were measured. The temporal variation of the bulk density and undrained shear strength were efficiently monitored by a radioisotope (RI) cone penetration test (Dasari et al., 2006).

\section{(c) Gravity Type Caisson Seawall}

Because the allowable displacement of the gravity type caisson seawall is very limited, particularly at the seawall nearby the approach light bridge, the cement deep mixing method (CDM) in block arrangement was utilized to improve the soft ground. The cross-section of the approach light seawall and tentative quay wall are shown in Figs. 8 and 9, respectively. The improvement depth was A.P. $-16.5 \mathrm{~m}$ to A.P. $-45.0 \mathrm{~m}$, and the length of each CDM column was $28.5 \mathrm{~m}$. To improve the soft ground of approximately $620,000 \mathrm{~m}^{3}$, a total of $4524 \mathrm{CDM}$ columns were installed.

\section{(d) Inside the Reclamation Fills}

Inside the reclamation fill, the soft ground was improved by sand drains (SD) to accelerate the consolidation behavior and, thus, decrease the amount of residual settlement during the in-service period. To achieve a degree of consolidation of $80 \%$ in the Yuc layer (depositing up to A.P. $-35 \mathrm{~m}$ with a coefficient of consolidation $c_{\mathrm{v}}$ of approximately $100 \mathrm{~cm}^{2} /$ day) at 4 months after staged filling, the arrangement of SDs $400-\mathrm{mm}$ in diameter was set at $2.5 \mathrm{~m} \times 1.6 \mathrm{~m}$. The SDs were installed up to A.P. $-35.5 \mathrm{~m}$ to A.P. $-37.5 \mathrm{~m}$ corresponding to the shallower depth of Ylc layer. The SD installation was conducted after placing the $1.5-\mathrm{m}$ thick sand mat drainage (with hydraulic conductivity higher than $1 \times$ $\left.10^{-4} \mathrm{~m} / \mathrm{s}\right)$. After the SD installation, 2.5-m thick sand layer (with hydraulic conductivity higher than $1 \times 10^{-5}$ $\mathrm{m} / \mathrm{s}$ ) was placed for SD head protection. There were $184,000 \mathrm{SD}$ piles of a total length reaching approximately $3,900,000 \mathrm{~m}$.

\section{Piled Pier Section}

In the pier section, to conduct the construction within the short period under the strict head clearance, a prefabricated jacket structure was adopted. A jacket unit is composed of an upper steel girder and lower steel pipe legs reinforced by a truss structure. The standard dimensions are $63 \mathrm{~m}$ in length, $45 \mathrm{~m}$ in width, $32 \mathrm{~m}$ in height, and $1300 \mathrm{t}$ in mass. A total 198 units of jacket were installed for the main body of the D-runway. 


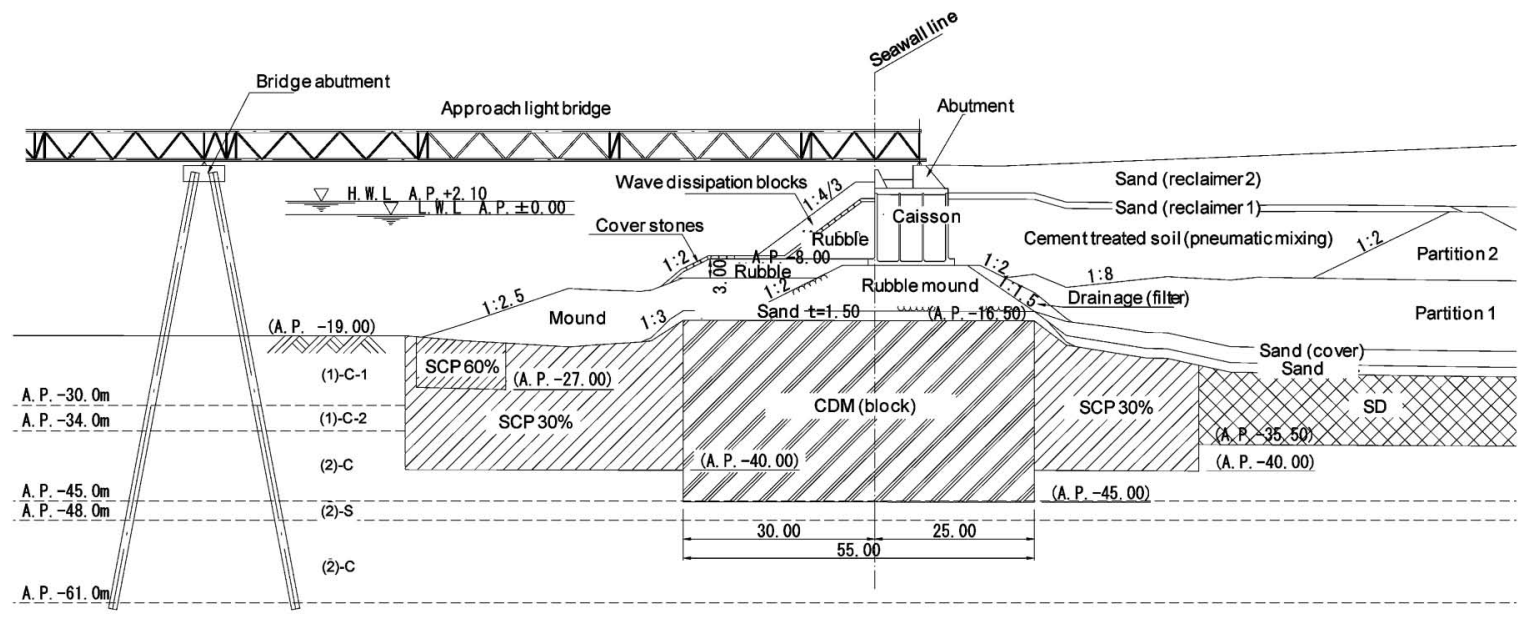

(3)-S

Fig. 8. A typical cross-section of the approach light seawall (gravity type caisson seawall)

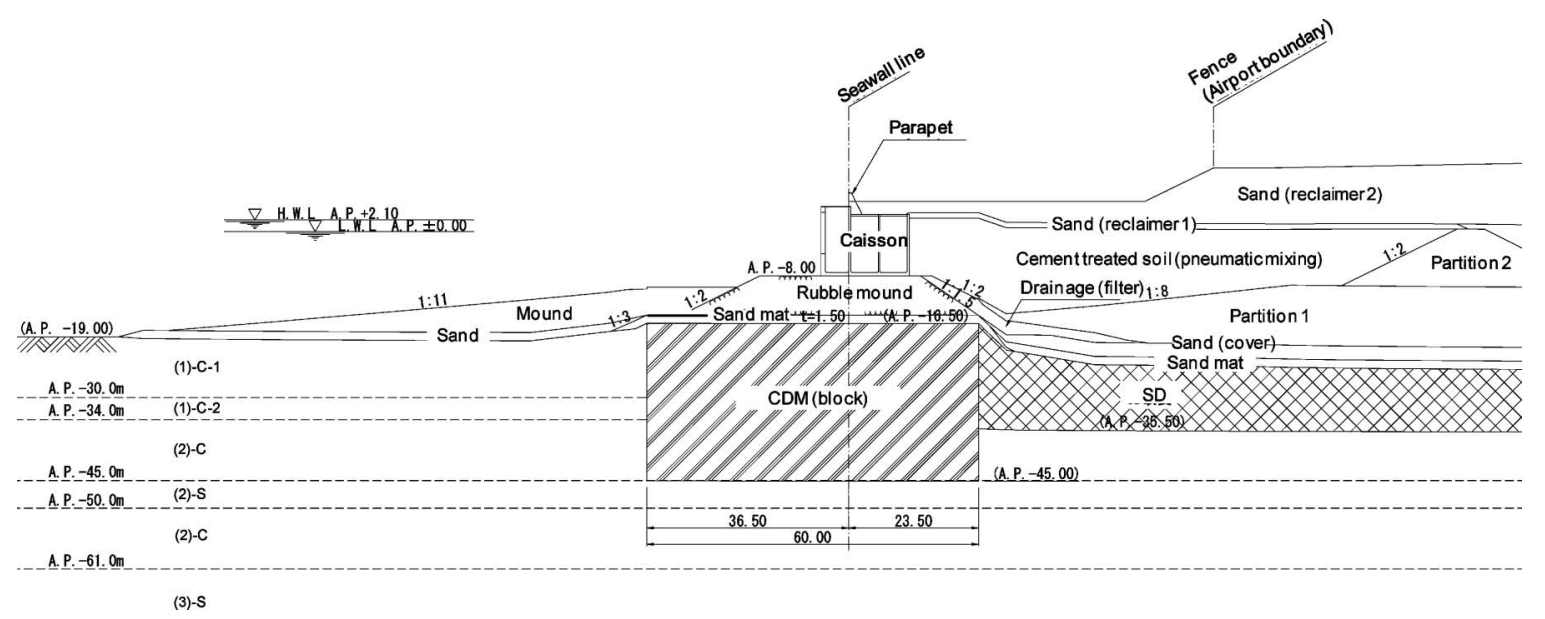

Fig. 9. A typical cross-section of the tentative quay wall

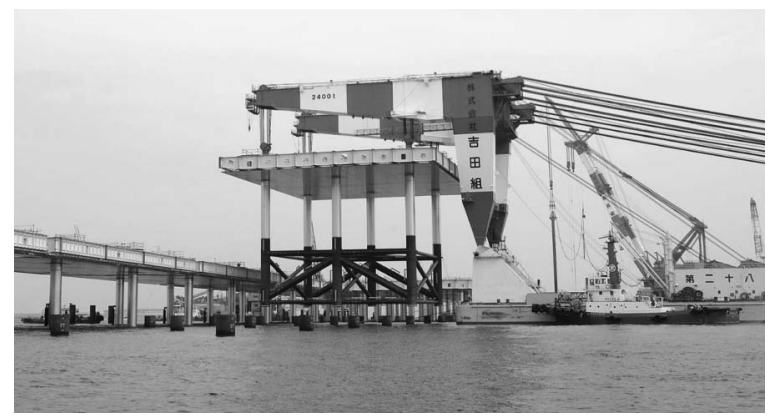

Photo 4. The installation of a jacket unit

In the assembling procedure of the jacket structure (Photo 4), six steel pipe piles were first driven to the ground, then the prefabricated jacket units were put into place by inserting the pile heads into the pipe legs, and then the clearance between the pile heads and legs was grouted by mortar. The standard dimensions of the steel pipe piles are $1600 \mathrm{~mm}$ in diameter and $90 \mathrm{~m}$ in length. The elevation of the pile heads after driving was A.P.

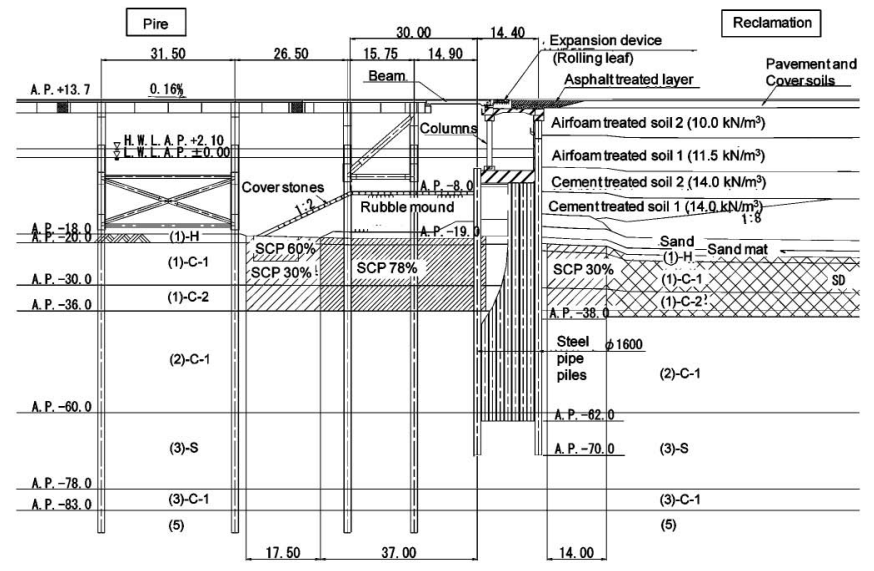

Fig. 10. Cross-section of the joint structure between the reclamation and pier sections

$+3.0 \mathrm{~m}$. Each jacket unit has 6 legs with dimensions of $1964 \mathrm{~mm}$ in diameter and $70 \mathrm{~mm}$ in thickness. After assembling the jackets, there were clearances of $2-3 \mathrm{~m}$ between any two adjacent jackets, and then a segments of 
adjusted dimensions were inserted into the clearances and welded into place, making an integrated body. The crosssection of the joint structures between the reclamation and pier sections is shown in Fig. 10. The piled foundations of the jackets were supported by the bearing layer (deeper than A.P. $-80 \mathrm{~m}$ ), which had $N$-values continuously greater than 50 . Because the evaluation of the bearing capacity of large-scale open-end piles is very difficult, a quick loading test (i.e., the stanamic test in Middendorp et al., 1992) was carried out to establish a reasonable bearing capacity formula.

\section{Joint Section}

The joint structure between the reclamation and pier sections is simply called the "joint section." The joint section is a very important structure which takes on the role of both the seawall of the manmade island and the abutment for the joint girder.

In this project, a well-foundation of steel pipe piles, which has a good track record in bridge foundations and abutments, was utilized (Fig. 10). The well-foundation has 24 consecutive rectangular cells consisting of an outer envelope of two parallel steel pipe sheet piles and 25 orthogonal steel pipe sheet piles.

A joint structure with a height of A.P. + 14 m was constructed in the soft clay deposit under the sea with a water depth of $15 \mathrm{~m}$. Because airplanes run at high speed for taking-off/landing on the joint structure, the amount of displacement allowed is strictly limited. There was considerable concern about the consolidation settlement and lateral soil movement of the reclamation section, as well as ground deformation in the event of an earthquake. In the design stage, an FEM analysis was carried out to evaluate the soil-structure interaction in both static and dynamic conditions (Niihara et al., 2010).

To ensure the stability of the well-foundation, which was embedded in the bearing layer, lightweight backfill, such as pneumatic mixing cement treated soil (Kitazume and Satoh, 2003) and air-foam treated lightweight soil (Tsuchida and Egashira, 2004), was utilized. Lightweight backfill contributes to a decrease in the lateral earth pressure, consolidation settlement, and lateral soil movement. In addition, the soft deposit in the front of the structure was improved by sand compaction piles with a high replacement ratio, which decreased the lateral displacement of the structure. Observational construction was conducted by monitoring the settlement and lateral movement caused by backfilling.

\section{SEAWALL STRUCTURE UTILIZING LIGHTWEIGHT SOILS}

\section{Effect of Lightweight Soils}

Cement treated lightweight soils made of dredged clay were backfilled to the seawall. The majority of the backfill of the mild slope rubble seawall (Fig. 7) was pneumatic mixing cement treated soil, which is appropriate for large scale construction work.

In the joint section, to reduce the earth pressure ap- plying to the well-foundation whose height is approximately $30 \mathrm{~m}$ from the seafloor surface, pneumatic mixing cement treated soil and air-foam treated lightweight soil were placed at the lower and upper sections, respectively (Fig. 10).

The total volume of lightweight soils (pneumatic mixing cement treated soil and airfoam treated lightweight soil) used in the reclamation work of the D-runway project was approximately $5,500,000 \mathrm{~m}^{3}$, which was equivalent to approximately $15 \%$ of total reclamation soil volume of approximately $38,000,000 \mathrm{~m}^{3}$.

\section{Design of Pneumatic Mixing Cement Treated Soil}

Pneumatic mixing cement treated soil is thought to be more economical than mountain sand, because the former makes use of the dredged soil, which means it does not have to be dumped at disposal facilities, but the latter means material has to be bought from a quarry. In fact, the dredged soil from the excavation works in front of the seawall and the moving work of the Tokyo Navigation Channel No. 1 were used as material soil. From another point of view, the use of lightweight soils reduces the net soil volume (i.e., the volume of soil particles) for reclamation, because of their high water content.

Despite these advantages, it was impossible to reclaim the D-runway Island using only lightweight soils since that would have required a long construction period and would have resulted in a low construction efficiency. Besides these considerations, due to their high fluidity, the necessary construction conditions would have been regions that had to be surrounded by dikes before the cement treated soils could be put in place.

After taking all the factors into account, the cross-section to be put into place by pneumatic mixing cement treated soil was designed, and is shown in Figs. 7-10. The maximum height of the pneumatic mixing cement treated soil was set at A.P. $+2.5 \mathrm{~m}$ (except Fig. 10). Common cross-sections were adopted in the seawalls on both sides of the island to ensure construction moved along efficiently.

Pneumatic mixing cement treated soil is a mixture of dredged soil and cement. Water is first added to the dredged soil to make a slurry with high fluidity, then some cement is added and the mixture is pumped with pressured air, then it is automatically mixed by plug flow, and then it is placed from the outlet. Its unit weight varies according to the physical properties of the soil used and the amount of added water. In approximately $85 \%$ of all the seawalls, the unit weight was set to be $15 \mathrm{kN} / \mathrm{m}^{3}$, because this value can be easily achieved by rapid construction. Meanwhile, in the backfills of both the caisson quay wall and well-foundation retaining wall, the unit weight was set to be $14 \mathrm{kN} / \mathrm{m}^{3}$, which required very strict quality control including the selection of the material soil. In the latter case, high plastic and homogeneous upper Yurakucho clay (Yuc) was selected as the material soil.

In terms of the shear strength of pneumatic mixing cement treated soil, an unconfined compression strength of more than $300 \mathrm{kN} / \mathrm{m}^{2}$ was required in order to avoid con- 
Table 1. An example of the mix proportion for the pneumatic mixing cement treated soil

\begin{tabular}{cc}
\hline $\begin{array}{c}W / C \text { in weight } \\
(\%)\end{array}$ & $\begin{array}{c}\text { Cement per unit weight of slurry } \\
C\left(\mathrm{~kg} / \mathrm{m}^{3}\right)\end{array}$ \\
\hline \multicolumn{2}{c}{ Dredged clay in front of the seawall } \\
\hline 10.2 & 85 \\
\hline Dreaded clay from Tokyo Navigation Channel No. 1 \\
\hline 8.5 & 103 \\
\hline
\end{tabular}

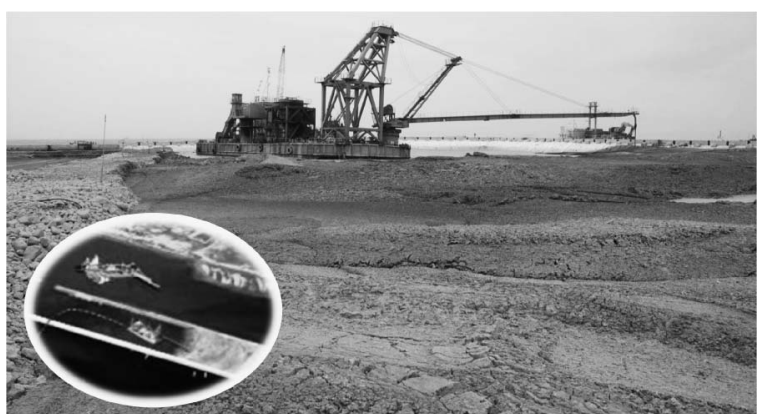

Photo 5. Putting the pneumatic mixing cement treated soil in place (inset: aerial photo showing the placement scene between the mild slope rubble seawall and partition)

solidation yielding under the overburden of effective stress. Moreover, differential settlement of the subsoil was a matter which had to be taken into consideration. Therefore, the residual compression strength was set at $300 \mathrm{kN} / \mathrm{m}^{2}$ after considering the potential deformation after curing, i.e., $300 \mathrm{kN} / \mathrm{m}^{2}$ was multiplied by a correction factor $(=1 / 0.85=1.2)$, and then $360 \mathrm{kN} / \mathrm{m}^{2}$ was set as the field compression strength $q_{\mathrm{uf}}$. This correction factor was determined based on the fact that the residual strength is approximately $85 \%$ of the peak strength in the triaxial CU test for cement treated soils (Watabe et al., 2000).

According to the technical manual (Coastal Development Institute of Technology, 2008a), a coefficient of variation $\mathrm{COV}$ of 0.35 and allowable defective percentage $P_{\mathrm{x}}$ of $25 \%$ can be assumed, and, consequently, the lower limit was set at $360 \mathrm{kN} / \mathrm{m}^{2}$. Then, the mean value of the data in the normal distribution of $471 \mathrm{kN} / \mathrm{m}^{2}$ was set as the mean value in the field strength $\bar{q}_{\mathrm{uf}}$. According to the technical manual, the unconfined compression strength used to determine the mix proportion $q_{\text {ul }}$ (unconfined compression strength in the laboratory) was set at 942 $\mathrm{kN} / \mathrm{m}^{2}$ with a strength ratio $q_{\mathrm{ul}} / \bar{q}_{\mathrm{uf}}$ of 2.0 . The value of this strength ratio was modified (decreased) by calibrating the value based on the laboratory test results for samples collected by check boring.

Because a sufficient curing period for the pneumatic mixing cement treated soil was secured before loading the design overburden stress, quality was controlled by the properties in 91 days, instead of 28 days, which is what is ordinarily used in many projects. A typical mix propor-

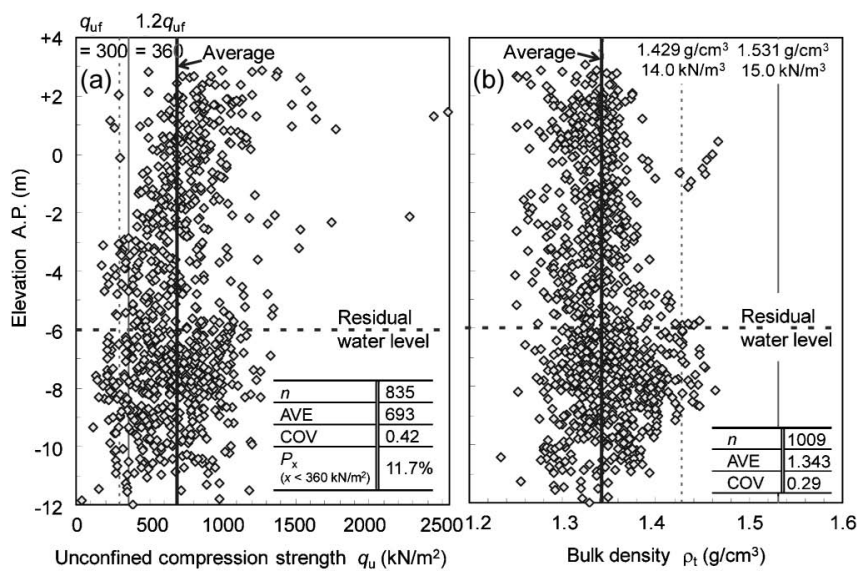

Fig. 11. Depth profiles of test results for samples (at 91 day) collected by check boring for pneumatic mixing cement treated soil: (a) unconfined compression strength; (b) bulk density

tion of the pneumatic mixing cement treated soil used in this project is shown in Table 1. A placement scene of the pneumatic mixing cement treated soil between the mild slope rubble seawall and partition is shown in Photo 5.

\section{Quality Control of Pneumatic Mixing Cement Treated Soil}

Approximately $4,700,000 \mathrm{~m}^{3}$ of pneumatic mixing cement treated soil was put into place over the period of one year from 21 October 2008 to 28 October 2009, including an interruption of about 2 months during work to close the open mouth (gateway) of the seawall. Three groups of plant ships were allocated in accordance with the progress of construction work on the seawalls and partitions.

The depth profiles of the unconfined compression strength $q_{\mathrm{u}}$ and the bulk density $\rho_{\mathrm{t}}$ of the samples collected by check boring are shown in Fig. 11. There are a few data showing significantly small strength (almost zero), which was due to sample disturbance with cracks. The average of the unconfined compression strength was 693 $\mathrm{kN} / \mathrm{m}^{2}$ with a percent defective of $11.7 \%$, and average bulk density of $1.343 \mathrm{~g} / \mathrm{cm}^{3}\left(13.17 \mathrm{kN} / \mathrm{m}^{3}\right.$ in unit weight). These values meet the required specifications mentioned above.

\section{Design of Air-foam Treated Lightweight Soil}

In the design of the air-foam treated lightweight soil, long-term durability and soil deformation had to be considered. Because the dry condition tends to accelerate the deterioration of this material (Watabe et al., 2007), the soil placed in this project was covered by $2-\mathrm{m}$ of sand and pavement to keep a moisture-rich condition.

Bulk density can be controlled in a range of $8-13 \mathrm{kN} /$ $\mathrm{m}^{3}$ by adjusting the mix proportion of material soil, water, and air-foam. In this project, because the air-foam treated lightweight soil was backfilled to the well-foundation retaining wall, its bulk density was required to be as small as possible.

However, to ensure long-term durability, the bulk density had to be larger than a certain value with low 
Table 2. An example of the mix proportion for the air-foam treated lightweight soil

\begin{tabular}{ccc}
\hline $\begin{array}{c}\text { Bulk density } \\
\text { of clay slurry } \\
\rho_{\mathrm{t}}\left(\mathrm{g} / \mathrm{cm}^{3}\right)\end{array}$ & $\begin{array}{c}\text { Cement per unit } \\
\text { weight of slurry } \\
C\left(\mathrm{~kg} / \mathrm{m}^{3}\right)\end{array}$ & $\begin{array}{c}\text { Volumetric percentage } \\
\text { of air-foam in mixture } \\
(\%)\end{array}$ \\
\hline & Target $\rho_{\mathrm{t}}=1.02 \mathrm{~g} / \mathrm{cm}^{3}\left(\gamma_{\mathrm{t}}=10 \mathrm{kN} / \mathrm{m}^{3}\right)$ \\
\hline 1.196 & 78 & 19.6 \\
\hline & Target $\rho_{\mathrm{t}}=1.12 \mathrm{~g} / \mathrm{cm}^{3}\left(\gamma_{\mathrm{t}}=11 \mathrm{kN} / \mathrm{m}^{3}\right)$ \\
\hline 1.211 & 47 & 11.8 \\
\hline
\end{tabular}

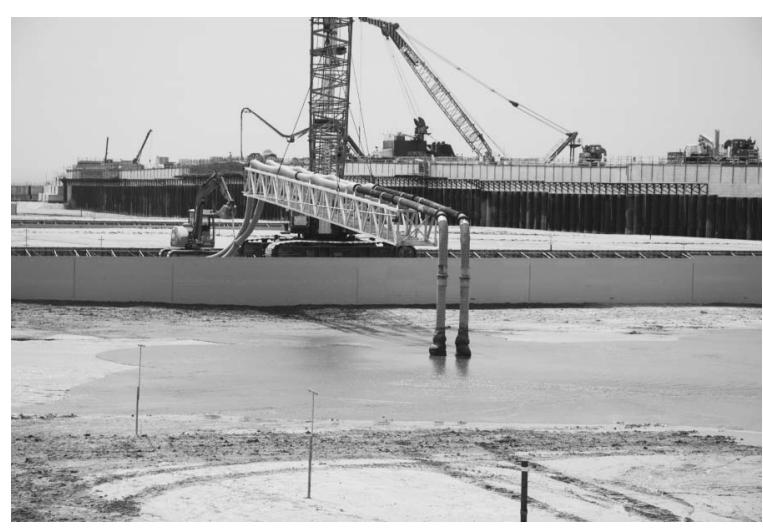

Photo 6. Putting the air-foam treated lightweight soil in place (background: the well-foundation of the joint section)

permeability, corresponding to a micro-structure in which the air bubbles are independent from each other (Watabe et al., 2004; Nagatome et al., 2010). Therefore, the unit weights above and below the residual ground water level were set at $10.0 \mathrm{kN} / \mathrm{m}^{3}$ and $11.5 \mathrm{kN} / \mathrm{m}^{3}$, respectively. Note here that the residual water level was assumed to be A.P. $+2.1 \mathrm{~m}$ in the design. Because longterm bulk density was expected to increase by $0.5 \mathrm{kN} / \mathrm{m}^{3}$ below the water level (Coastal Development Institute of Technology, 2008b), the target bulk density in the placing work was set to be $11.0 \mathrm{kN} / \mathrm{m}^{3}$ instead of $11.5 \mathrm{kN} / \mathrm{m}^{3}$. The section where the soil was placed above the water level and would submerge (because of consolidation settlement) was classified as "below water level." The calculated residual settlement at the backfill of the well-foundation retaining wall was estimated to be approximately $1 \mathrm{~m}$ during a 100-year in-service period.

The dredged soil from the moving work of the Tokyo Navigation Channel No. 1 was used as the material soil. An unconfined compression strength of greater than 200 $\mathrm{kN} / \mathrm{m}^{2}\left(=\bar{q}_{\mathrm{uf}}\right)$ was required in order to avoid consolidation yielding under the overburden effective stress. According to the technical manual (Coastal Development Institute of Technology, 2008b), the unconfined compression strength used to determine the mix proportion $q_{\mathrm{ul}}$ was set to be $440 \mathrm{kN} / \mathrm{m}^{2}$, calculated with a strength ratio $q_{\mathrm{ul}} / \bar{q}_{\mathrm{uf}}$ of 2.2 . The quality was controlled by the properties of 91 days, instead of the 28 days ordinarily used in many projects, as with the pneumatic mixing cement treated soil. A typical mix proportion of the air-foam
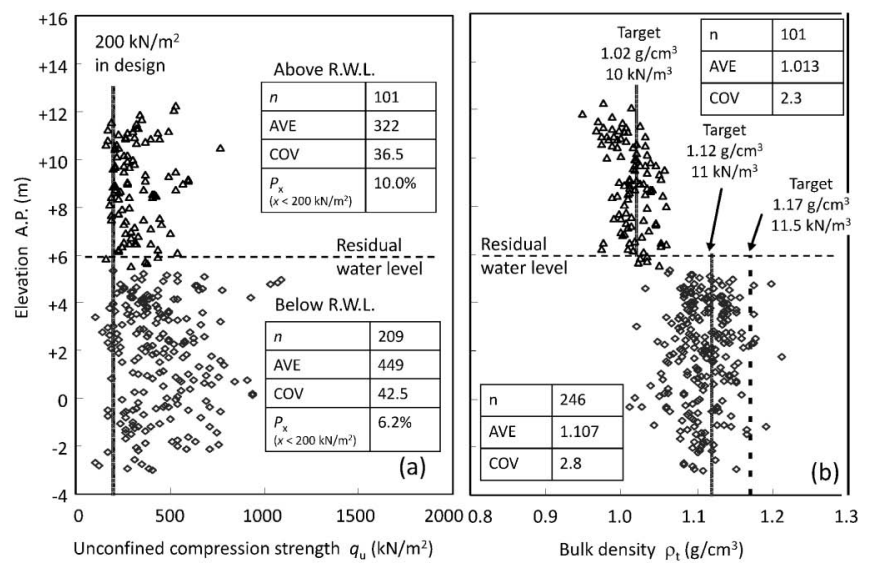

Fig. 12. Depth profiles of test results for samples (at 91 day) collected by check boring for air-foam treated lightweight soil: (a) unconfined compression strength; (b) bulk density

treated lightweight soil used in this project is shown in Table 2. A placement scene of the air-foam treated lightweight soil is shown in Photo 6.

\section{Quality Control of Air-foam Treated Lightweight Soil}

Approximately $790,000 \mathrm{~m}^{3}$ of air-foam treated lightweight soil was put into placed using two groups of plant ships, and this took over 6 months from 19 May 2009 to 28 November 2009. In the 13-years history of air-foam treated lightweight soil before this project, the total volume of air-foam treated lightweight soil used was approximately $520,000 \mathrm{~m}^{3}$. The soil volume put into place within six months in this project was equivalent to 1.5 times the total previous record.

The depth profiles of unconfined the compression strength $q_{\mathrm{u}}$ and bulk density $\rho_{\mathrm{t}}$ for samples collected by check boring are shown in Fig. 12. The average unconfined compression strength was $449 \mathrm{kN} / \mathrm{m}^{2}$ and 322 $\mathrm{kN} / \mathrm{m}^{2}$ above and below the residual ground water level, respectively, with percent defective of $9.2 \%$. The average bulk density was $0.987 \mathrm{~g} / \mathrm{cm}^{3}$ and $1.089 \mathrm{~g} / \mathrm{cm}^{3}(9.68$ $\mathrm{kN} / \mathrm{m}^{3}$ and $10.68 \mathrm{kN} / \mathrm{m}^{3}$ in unit weight) above and below the residual ground water level, respectively. These values met the required specifications in the design.

\section{SETTLEMENT PREDICTION IN THE RECLAMATION SECTION}

\section{Development of Settlement Prediction System}

During the construction period when primary consolidation was progressing, the final land reclamation height had to be determined after considering both the primary and secondary consolidation settlements. The short construction period made it difficult to predict the amount of consolidation settlement, since it was not enough time for the primary consolidation to be completed.

The reclamation work was conducted by two groups from both ends of the island to the center, where the seawall had an open mouth as gateway. In addition, various kinds of reclamation fill materials in different unit 
weights, such as mountain sand, rock debris, pneumatic mixing cement treated soil, and air-foam treated lightweight soil were used. These conditions may result in an uneven stress history, and therefore a differential in settlement.

To accurately predict the long-term settlement during an in-service period of 100 years, a consolidation settlement prediction system was developed (Mizuno et al., 2010). This system consists of a stress history database (the progress of construction), a geotechnical condition database (the geological cross-section and soil parameters), and an FEM analysis solver. The settlement was predicted using this system three times in total, i.e. the original prediction was done with the soil parameters obtained from the ground investigation and the first modification for the primary consolidation behavior in July 2009, and the second was based on modifications were made after considering the long-term consolidation (secondary consolidation) behavior in October 2009. In this calculation, the clay layers were modeled as the elasto-viscoplastic model, which was proposed by Sekiguchi and Ohta (1977). This constitutive model can consider anisotropy for the Cam-clay model and has been used in many construction projects in Japan. In the calculation, the soil layers were modeled by an axisymmetrical mesh around the center of each column of SD, SCP or $\mathrm{CDM}$ for the improved layers in (1)-C and (2)-C. Figure 13 shows the FEM mesh used in the case of SD. The elements representing SD can be replaced by SCP or CDM. Note here that the mesh size was adjusted corresponding to the column diameter of the SD, SCP and CDM, respectively. The SD elements are modeled as stiff elastic bodies independent from the surrounding clay; however, the pore water pressure was coupled between the corresponding nodes. In other words, coupling between the SD and surrounding clay was considered in the pore water pressure; however, it was not considered in the deformation. The SCP elements are modeled as the surrounding clay with reduced $C_{\mathrm{c}}$ and $C_{\mathrm{s}}$ at 0.625 times using a stress distribution ratio of $n=3$ and a replacement area ratio of $a_{\mathrm{s}}=30 \%$, i.e., $n /\left\{1+(n-1) a_{\mathrm{s}}\right\}=0.625$. Hydraulic conductivity was set at $1 \times 10^{-4} \mathrm{~m} / \mathrm{s}$ for the SD and $1 \times$
$10^{-5} \mathrm{~m} / \mathrm{s}$ for the SCP. The CDM elements were assumed to be zero settlement (very stiff). The clay layers below unimproved (2)-C were modeled as a one-dimensional line element. The thick sand layers were assumed to be full drainage, but the thin sand layers were ignored. Therefore, output is a one-dimensional settlement at each point; however, the system can integrate the three-dimensional settlement distribution in consideration of stress distribution. In addition, the variation of buoyancy force acting on the fill materials was considered in association with consolidation settlement.

The data stored in the stress history database are allocated to a $5 \mathrm{~m} \times 5 \mathrm{~m}$ mesh size. The data sets before July 2009 and after August 2009 were observed and scheduled, respectively, in the original prediction and first modification, and those were updated in October 2009 in the sec-

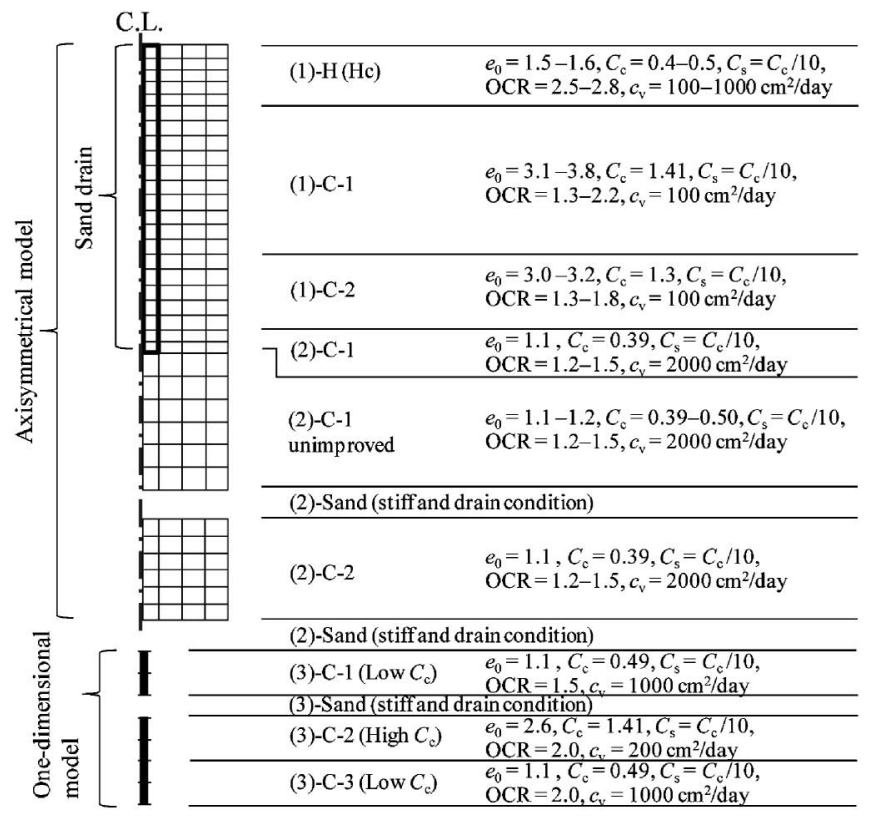

Fig. 13. FEM mesh in case of SD and list of input parameters. The elements representing SD can be replaced by SCP or CDM. The mesh is modeled as axisymmetrical for layers (1) and (2) and one-dimensional for layer (3)

Table 3. List of soil parameters for clayey layers in the FEM analysis

\begin{tabular}{|c|c|c|c|c|c|c|}
\hline Layers & $\begin{array}{c}\text { Void ratio } \\
e_{0}\end{array}$ & $\begin{array}{c}\text { Compression } \\
\text { index } \\
C_{\mathrm{c}}\end{array}$ & $\begin{array}{l}\text { Swelling index } \\
\qquad C_{\mathrm{s}}\end{array}$ & $\begin{array}{l}\text { Over- } \\
\text { consolidation } \\
\text { ratio OCR }\end{array}$ & $\begin{array}{l}\text { Coefficient of } \\
\text { consolidation } \\
c_{\mathrm{v}}\left(\mathrm{cm}^{2} / \text { day }\right)\end{array}$ & $\begin{array}{c}\text { Secondary } \\
\text { consolidation index } \\
\alpha\end{array}$ \\
\hline (1)-C & $\begin{array}{c}3.1-3.8 \\
(3.0-3.6)\end{array}$ & $\begin{array}{c}1.30-1.41 \\
(1.30-1.41)\end{array}$ & $\begin{array}{c}0.130-0.141 \\
(0.130-0.141)\end{array}$ & $\begin{array}{l}1.3-2.2 \\
(1.3)\end{array}$ & $\begin{array}{c}100 \\
(100)\end{array}$ & $\begin{array}{c}0.00375-0.00426 \\
(0.00538-0.00564)\end{array}$ \\
\hline $\begin{array}{l}\text { (2)-C } \\
\text { (improved) }\end{array}$ & $\begin{array}{c}1.1 \\
(1.1)\end{array}$ & $\begin{array}{c}0.39 \\
(0.39)\end{array}$ & $\begin{array}{c}0.039 \\
(0.039)\end{array}$ & $\begin{array}{l}1.2-1.5 \\
(2.45)\end{array}$ & $\begin{array}{c}2000 \\
(1000)\end{array}$ & $\begin{array}{c}0.00251 \\
(0.00331)\end{array}$ \\
\hline $\begin{array}{l}\text { (2)-C } \\
\text { (unimproved) }\end{array}$ & $\begin{array}{l}1.1-1.2 \\
(1.1)\end{array}$ & $\begin{array}{l}0.39-0.50 \\
\quad(0.39)\end{array}$ & $\begin{array}{l}0.039-0.050 \\
(0.039)\end{array}$ & $\begin{array}{l}1.2-1.5 \\
(2.45)\end{array}$ & $\begin{array}{l}2000 \\
(1000)\end{array}$ & $\begin{array}{c}0.00251 \\
(0.00331)\end{array}$ \\
\hline $\begin{array}{l}(3)-C \\
\left(\text { Low } C_{c}\right)\end{array}$ & $\begin{array}{l}1.1 \\
(1.1)\end{array}$ & $\begin{array}{c}0.49 \\
(0.49)\end{array}$ & $\begin{array}{c}0.049 \\
(0.049)\end{array}$ & $\begin{array}{l}1.5-2.0 \\
(2.5)\end{array}$ & $\begin{array}{l}200 \\
(200)\end{array}$ & $\begin{array}{c}0.00749 \\
(0.00393)\end{array}$ \\
\hline $\begin{array}{l}(3)-\mathrm{C} \\
\left(\mathrm{High} C_{\mathrm{c}}\right)\end{array}$ & $\begin{array}{l}2.6 \\
(2.6)\end{array}$ & $\begin{array}{c}1.41 \\
(1.41)\end{array}$ & $\begin{array}{c}0.141 \\
(0.141)\end{array}$ & $\begin{array}{r}2.0 \\
(2.5)\end{array}$ & $\begin{array}{c}1000 \\
(1000)\end{array}$ & $\begin{array}{c}0.00745 \\
(0.00675)\end{array}$ \\
\hline
\end{tabular}


ond modification. In the calculation, a Bousinesque stress distribution was considered. The data stored in the geotechnical condition database are allocated to a $20 \mathrm{~m} \times 20$ $\mathrm{m}$ mesh in plane with 15 stratified layers based on the results of the geotechnical investigation.

The input parameters used in this calculation are summarized in Table 3. These soil parameters were input in the original prediction as the parenthetic values, which were evaluated based on the ground investigation (Figs. 4, 5 and 6), but adjusted in the first modification corresponding to the progress of the construction work by inverse analysis (i.e., fitting) for the observational consolidation settlement, except for the secondary consolidation index $\alpha$, which was not adjusted in the fitting. Note here that the parenthetic value of $\alpha$ was assumed to be $\alpha=$ $0.434 \times 0.04 \times C_{\mathrm{c}} /\left(1+e_{0}\right)$. The original coefficient of consolidation of $1000 \mathrm{~cm}^{2} /$ day in both Layers (2)-C and (3)-C was conservative because of this very large value; however, it can be almost doubled in the fitting to the measured consolidation behavior. The original value of $c_{\mathrm{v}}$ shown here corresponds to the normal consolidation state. The value of $c_{\mathrm{v}}$ corresponds to the over consolidation state and is much higher than this; however it is not reliable because the settlement in the laboratory test is too rapid. The modified value of $c_{\mathrm{v}}$ is increased by fitting and is consistent with that transition occurs from overconsolidation to normal consolidation. The overconsolidation ratio of OCR in both Layers (2)-C and (3)-C was as large as 2.5 , but it can be significantly decreased to $1.2-1.5$ since the yielding point in the compression curve is not clear with increasing $C_{\mathrm{c}}$ (i.e., compression curve is always convex upward) and the consolidation pressure after the reclamation fill is relatively close to the consolidation yield stress at these large depths. The point is that the soil parameters evaluated based on the ground investigation had to be modified corresponding to the stress level in the practice.

Because the main objective of this calculation is to predict the long-term consolidation settlement for the inservice period of 100 years, the key factor is the viscosity
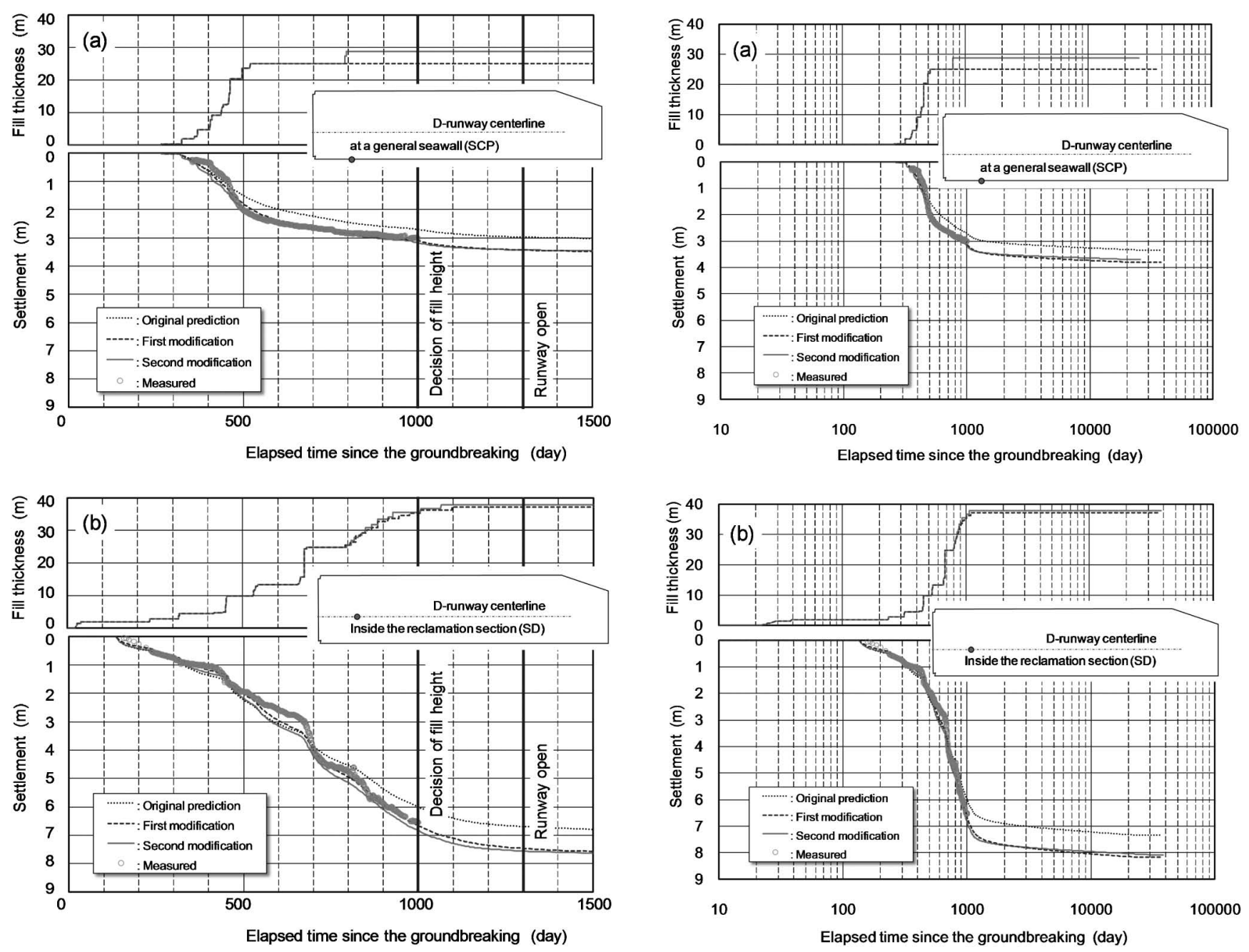

Fig. 14. A comparison between settlement prediction and actual observations up to $t=1500$ day; (a) at a general seawall (SCP with replacement ration of $30 \%$ ); (b) inside the reclamation section (SD installation). Elapsed time in these figures is started on 30 March 2007

Fig. 15. Temporal variations of settlement prediction and measurement in a logarithmic time scale up to 100 years; (a) at a general seawall (SCP with replacement ration of $30 \%$ ); (b) inside the reclamation section (SD installation). The amount of time elapsed in these figures was calculated from 30 March 2007 
parameters, i.e., the secondary consolidation index $\alpha=$ $0.434 C_{\alpha} /\left(1+e_{0}\right)$ and initial viscoplastic strain rate $\dot{v}_{0}$. In the second modification, these parameters were determined based on the isotache concept (Šuklje, 1957; Watabe et al., 2008). In the isotache concept, the secondary consolidation index $\alpha$ tends to decrease with time. Sekiguchi and Ohta's elasto-viscoplastic model is one of the isotache type models; however, this is a special case in which the value of $\alpha$ remains constant with time. Consequently, the average $\alpha$ value from the end of primary consolidation (assumed to be at $t=1500$ day from the commencement of construction work) to 30 years after was used for the calculation. The initial strain rate $\dot{v}_{0}$ was determined as $\dot{v}_{0}=\alpha / t$ on the assumption of $t=1500$ day. Note here that the assumption of $t=1500$ day as end of primary consolidation is consistent with the estimated consolidation period with $c_{\mathrm{v}}=1000 \mathrm{~cm}^{2} /$ day.

Examples of comparison between the settlement predictions and observations up to 1500 day; (a) at a general seawall (SCP with replacement ratio of 30\%) indicated in the inset and (b) inside the reclamation section (SD installation) indicated in the inset, are shown in Fig. 14. The elapsed time is started on 30 March 2007 corre- sponding to the commencement of this construction. Because the original prediction curve showed smaller settlement than the measurement, the consolidation yield stress $p_{\mathrm{c}}$ was decreased in the first modification (see Table 3 ). Therefore, the first modification is in agreement with the measurement as of September 2009 (approximately 900 days), indicating that future predictions were likely to have higher reliability. In fact, recent data observed after September 2009 are in concordance with those predicted as of today. The difference between the first modification and second modification is not significant in this figure up to 1500 days (May 2011).

To compare the long-term consolidation behavior up to 100 years (approximately 36,500 days) in association with secondary consolidation, temporal variations of settlement prediction and measurement in a logarithmic time scale are shown in Fig. 15. There is some difference between the first and second modifications after 1500 day, i.e., the long-term settlement calculated in the second modification is smaller by $0.10-0.11 \mathrm{~m}$ than that calculated in the first modification at 36,500 day. This corresponds to the fact that the second consolidation index $\alpha$ was decreased based on the interpretation of long-term

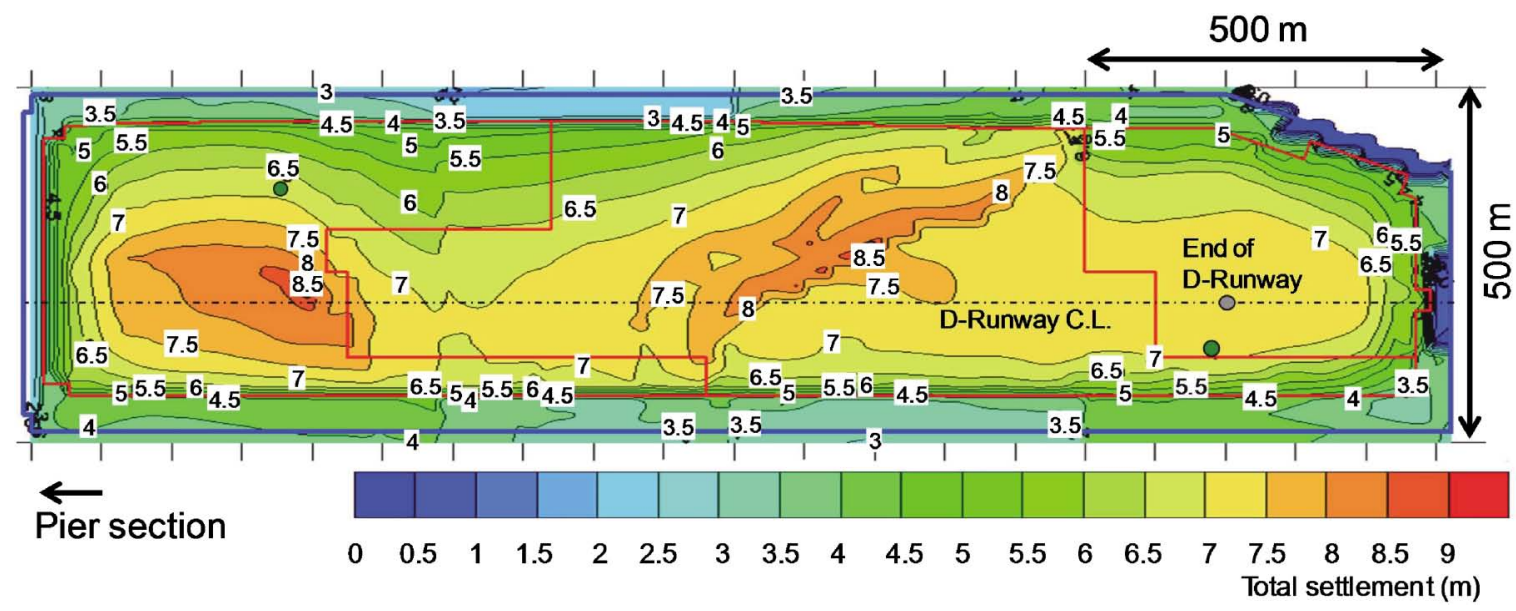

Fig. 16. Contours of the predicted total settlement

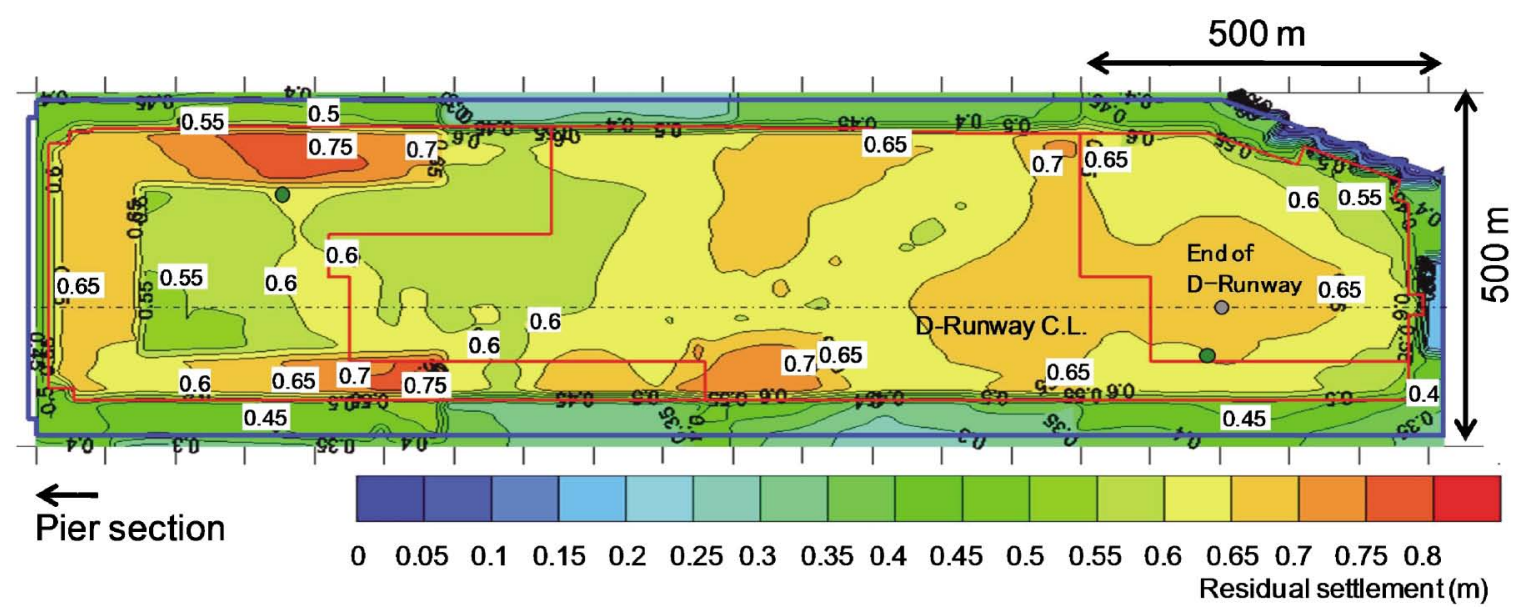

Fig. 17. Contours of the the predicted residual settlement for a 100-year in-service period 
consolidation behavior with the isotache concept, which resulted in a smaller $\alpha$ value than the original assumption.

\section{Determination of Final Land Reclamation Height}

Incremental consolidation pressure from the reclamation fill was approximately $550 \mathrm{kN} / \mathrm{m}^{2}$ and $300 \mathrm{kN} / \mathrm{m}^{2}$ near the offshore end and near the joint section, respectively, of the D-runway. Contours of total settlements calculated in the second modification at $20 \mathrm{~m} \times 20 \mathrm{~m}$ mesh nodes are shown in Fig. 16. Total settlements as large as $8.0 \mathrm{~m}$ were calculated near the center and joint section of the D-runway. These regions correspond to the border of previous sand fill to create shallow sea (see Fig. 3 , indicted as $\mathrm{Hc}$ ), indicating that stress history is a key factor to predict total settlement. These also correspond to the distribution of younger Nac layer deposited in an eroded valley in the Toc layer (see Figs. 3, 5 and 6), indicating that geological history is another key factor to take into acount. The predicted total settlement on average was $7.2 \mathrm{~m}$.

Contours of residual settlements calculated in the second modification for in-service period of 100 years are shown in Fig. 17. The residual settlement is not directly linked to the total settlement. The predicted residual settlement along the D-runway was $0.50-0.65 \mathrm{~m}$ and $0.60-0.70 \mathrm{~m}$ near the joint section and end of the runway, respectively. The seawall sections, where significant residual settlement of more than $0.7 \mathrm{~m}$ was calculated, correspond to the position of late backfilling, because these sections were used as either the open mouth (gateway) for ships/barges used for reclamation filling or for the tentative material yard.

A summary of the above results with regard to longterm settlement is as follows: residual settlement for a 100-year in-service period at the highest point (the end) of the D-runway was expected to be $0.69 \mathrm{~m}(0.73 \mathrm{~m}$ after completion of filling). Consequently, in consideration of the residual settlement, the filling of the D-runway at the start of in-service period was decided in December 2009 (approximately 1000 day) to be $0.70 \mathrm{~m}$ (slightly larger than $0.69 \mathrm{~m}$ ) higher than the design elevation, which was determined according to what is required for aviation operation.

\section{SUMMARY}

One of the remarkable features of the D-runway is its hybrid structure, consisting of piled pier and reclamation fill. The former section was adopted in the river mouth of the Tama River to ensure a flow rate during times of flooding. This piled pier section was constructed by assembling jackets which were prefabricated in a factory yard to shorten the construction period. On the other hand, the latter section, i.e., the manmade island, is actually a high embankment. Its elevation at the offshore end of the D-runway was required to be higher than A.P. $+17.1 \mathrm{~m}$, because airplanes have to pass over large ships navigating in the vicinity.

From the ground investigation, a geological cross-sec- tion was first clarified with the soil layers referred to as $\mathrm{Y}$ (the Yurakucho layer), $\mathrm{Na}$ (the Nanago layer), To (the Tokyo layer) and Ed (the Edogawa layer) with subscripts c (clay), s (sand) and g (gravel), then the engineering ground cross-section was classified into 5 layers (1)-(5). Layer (1) is a soft clay deposit, which had to be stabilized for construction. Layer (2) is low plastic silty clay with $I_{\mathrm{p}}$ of approximately 15 . During the construction, because of the large coefficient of consolidation, ground improvement technology was not required for this layer. Layer (3) consists of To (Tokyo layer) with alternate gravel, sand and clay layers. The undrained shear strength $c_{\mathrm{u}}$ and consolidation yield stress $p_{\mathrm{c}}$ for the clay were able to be expressed by extrapolation of the depth profiles in layer (2); however, there is a relatively weak region which consists of Nac. Both geotechnical and geological knowledge needed to be taken into consideration in order to make an interpretation of the ground condition. Layers (4) and (5) are able to be bearing layers, but the former is a little weaker than the latter.

The soft subsoil under the mild slope rubble seawall, where a rather large amount of deformation is allowable, and under the gravity type caisson seawall, where the amount of deformation allowed is quite small, was improved by the SCP (low replacement ratio) and CDM (block type), respectively. In addition, lightweight soils were backfilled to the seawalls to shorten the working period and to save on ground improvement costs.

The upper soft subsoil was improved by the SD method to accelerate consolidation; however, it was expected that the lower clayey layer, which cannot be improved because of the large depths involved, would cause a long-term settlement of approximately $0.70 \mathrm{~m}$. Consequently, considering the amount of the residual settlement likely, enough filling was used for the D-runway to make it 0.70 $m$ higher than the design elevation.

In the construction of the D-runway, not only the ground improvement technologies (SD, SCP, and CDM) but also the new developed construction materials (pneumatic mixing cement treated soil and air-foam treated lightweight soil) were utilized.

In the-D-runway project, various technologies accumulated through previous airport constructions were applied to the ground investigation, the design, the construction work, and also the maintenance. The construction of the D-runway was completed safely, rapidly, and economically, and it went into operation on 21 October 2010, on schedule.

\section{ACKNOWLEDGMENTS}

This paper was written in collaboration with Kanto Regional Development Bureau of Ministry of Land, Infrastructure, Transport and Tourism, Port and Airport Research Institute, and Joint Venture for D-runway construction in the further expansion project of Haneda Airport. Particularly, the authors would like to acknowledge Mr. J. Satoh (Shimizu Corporation), Mr. Y. Niihara (Kajima Corporation), Mr. N. Oku, Mr. Y. Mitarai, Mr. 
T. Sakaiya, Mr. R. Yamatoya, Mr. M. Takahashi (Toa Corporation), Mr. T. Kawabata, Mr. K. Mizuno (Wakachiku Construction Co., Ltd.), Mr. T. Ogura (Toyo Construction Co., Ltd.), Mr. K. Kakehashi, and Mr. M. Watanabe (Penta-Ocean Construction Co., Ltd.).

\section{REFERENCES}

1) Berre, T. and Bjerrum, L. (1973): Shear strength of normally consolidated clays, Proc. 8th Int. Conf. Soil Mech. Found. Engrg, Moscow, 39-49.

2) Coastal Development Institute of Technology (2008a): Technical manual for pneumatic mixing cement treated soil (revised edition), 16-20 (in Japanese).

3) Coastal Development Institute of Technology (2008b): Technical manual for air-foam treated lightweight soil (revised edition) (in Japanese).

4) Dasari, G. R., Karthikeyan, M., Tan, T.-S, Mimura, M., Phoon, K.-K. (2006): In situ evaluation of radioisotope cone penetrometers in clays, Geotech. Testing J., 29(1), 45-53.

5) EN 1997-1: 2004: Eurocode 7, Geotechnical design-Par 1: General rules.

6) Essex, R. J. (2007): Geotechnical baseline reports for construction, suggested guidelines, The Technical Committee on Geotechnical Reports of the Underground Technology Research Council, American Society of Civil Engineers.

7) Furudoi, T. (2010): The second phase construction of Kansai International Airport considering the large and long-term settlement of the clay deposits, Soils and Foundations, 50(6), 805-816.

8) Hanzawa, H. (1983): Undrained strength characteristics of normally consolidated aged clay, Soils and Foundations, 23(3), 39-49.

9) Japan Port and Harbour Association (1999): Technical standards, and commentaries for port and harbour facilities (in Japanese).

10) Japan Port and Harbour Association (2007): Technical standards, and commentaries for port and harbour facilities (in Japanese).

11) JGS 4001: 2004: Principles for foundation design grounded on performance based design concept, Japanese Geotechnical Society.

12) Kanto Regional Development Bureau, Ministry of Land, Infrastructure, Transport and Tourism (2004): The Reference Geotechnical Data Sets for D-runway Project (in Japanese).

13) Katayama, T. (1991): Meeting the challenge to the very soft ground-the Tokyo International Airport Offshore Expansion Project, Proc. Int. Conf. Geotech. Engrg for Coastal Development, GEO-COAST'91, 954-967.

14) Kitazume, M. and Satoh, T. (2003): Development of pneumatic flow mixing method and its application to Central Japan International Airport construction, J. Ground Improvement, 7(3), 139148.

15) Middendorp, P., Bermingham, O. and Kuiper, B. (1992): Stanamic load testing of foundation piles, Proc. 4th Int. Conf. Application of Stress-Wave Theory to Piles, 581-588.

16) Mesri, G. (1975): New design procedure for stability of soft clays, Discussion, ASCE J. Geotech. Engrg, 101(4), 409-412.

17) Mizuno, K., Yamada, K., Aoki, Y., Yamamoto, T., Takahashi,
M., Kobayashi, M., Watabe, Y. and Noguchi, T. (2010): Longterm consolidation settlement prediction in Tokyo International Airport D-Runway, Proc. 9th Symp. Ground Improvement, the Society of Material Science, Japan, 351-356 (in Japanese).

18) Nagatome, T., Hashimoto, T., Otani, J. and Kikuchi, Y. (2010): Absorption property evaluation of light weight soil with air foam due to different mixing conditions, J. Society of Materials Science, Japan, 59(1), 68-73, doi: 10.2472/jsms.59.68 (in Japanese).

19) Nakase, A. (1967): The $\phi_{\mathrm{u}}=0$ analysis of stability and unconfined compression strength, Soils and Foundations, 7(2), 33-45.

20) Niihara, Y., Yoshihara, T., Nagashima, S., Murakami, T., Noguchi, T. and Miyata, M. (2010): Design of large-scale seawall structure with high strength joint and observation of its real behavior, Annual J. Civil Engrg in the Ocean, Japan Soc. Civil Engrs, 26 (in Japanese).

21) Overseas Coastal Area Development Institute of Japan (2002): Technical standards, and commentaries for port and harbour facilities in Japan.

22) Overseas Coastal Area Development Institute of Japan (2009): Technical standards, and commentaries for port and harbour facilities in Japan.

23) Sekiguchi, H. and Ohta, H. (1977): Induced anisotropy and time dependency in clays, constitutive equation of soils, Proc. Specialty Session 9, 9th Int. Conf. Soil Mech. Found. Engrg, Tokyo, 306-315.

24) Suklje, L. (1957): The analysis of the consolidation process by the isotache method, Proc. 4th Int. Conf. Soil Mech. Found. Engng, London, 200-206.

25) Tsuchida, T. and Egashira, K. (ed.) (2004): The lightweight treated soil method, A. A. Balkema.

26) Watabe, Y., Tsuchida, T., Furuno, T. and Yuasa, H. (2000): Mechanical characteristics of a cement treated dredged soil utilized for waste reclamation landfill, Proc. Int. Symp. Coastal Geotech. Engrg in Practice, IS-Yokohama 2000, 739-745.

27) Watabe, Y., Tsuchida, T. and Adachi, K. (2002): Undrained shear strength of Pleistocene clay in Osaka Bay, J. Geotech. Geoenv. Engrg, 128(3), 216-226.

28) Watabe, Y., Tanaka, M., Tanaka, H. and Tsuchida, T. (2003): $K_{0^{-}}$ consoliation in a triaxial cell and evaluation of in-situ $K_{0}$ for marine clays with various characteristics, Soils and Foundations, 43(1), $1-20$.

29) Watabe, Y., Itou, Y., Kang, M.-S. and Tsuchida, T. (2004): Onedimensional compression of air-foam treated lightweight geomaterial in microscopic point of view, Soils and Foundations, 44(6), 53-67.

30) Watabe, Y., Saegusa, H., Ueda, T., Shiina, T., Shiraishi, Y. and Murakami, T. (2007): Characteristics and countermeasures for the deterioration of Air-foam treated lightweight soil, Japanese Geotech. J., 2(4), 311-318, doi: 10.3208/jgs.2.311 (in Japanese).

31) Watabe, Y., Udaka, K. and Morikawa, Y. (2008): Strain rate effect on long-term consolidation of Osaka bay clay, Soils and Foundations, 48(4), 495-509.

32) Watabe, Y., Tanaka, M. and Kikuchi, Y. (2009): Practical determination method for soil parameters adopted in the new performance based design code for port facilities in Japan, Soils and Foundations, 49(6), 827-839. 